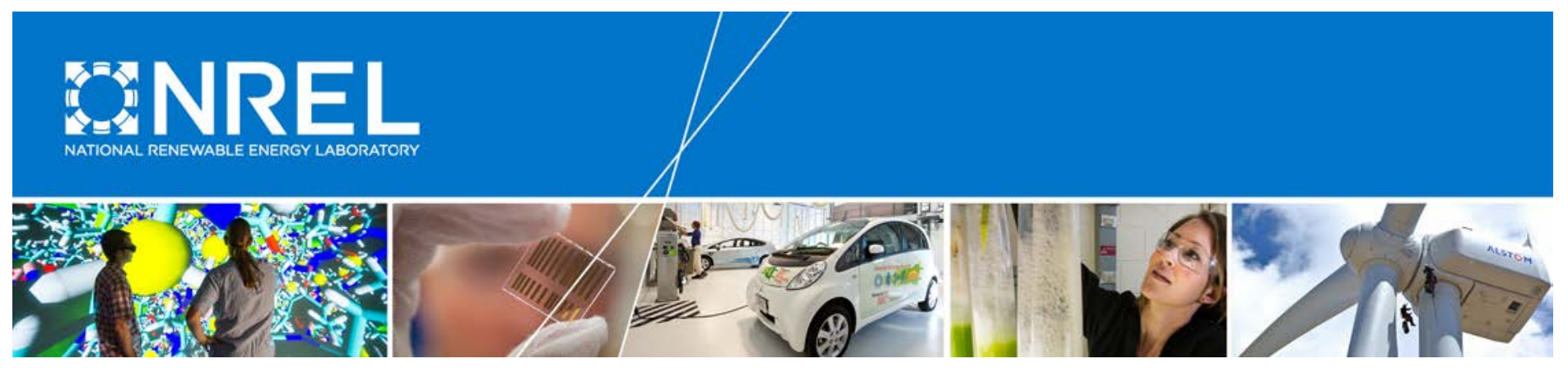

\title{
Fixed Point Raptor Migration Survey at the National Wind Technology Center
}

\section{April 2010}

John A. Du Waldt

Eco-Logic, LLC

Evergreen, Colorado

NREL Technical Monitor: Brenda Beatty

NREL is a national laboratory of the U.S. Department of Energy Office of Energy Efficiency \& Renewable Energy

Operated by the Alliance for Sustainable Energy, LLC

This report is available at no cost from the National Renewable Energy Laboratory (NREL) at www.nrel.gov/publications.

\section{Subcontract Report}

NREL/SR-1900-70460

June 2018 


\title{
Fixed Point Raptor Migration Survey at the National Wind Technology Center
}

\section{April 2010}

\author{
John A. DuWaldt \\ Eco-Logic, LLC \\ Evergreen, Colorado
}

NREL Technical Monitor: Brenda Beatty

\section{Suggested Citation}

Du, Waldt, John A. 2018. Fixed Point Raptor Migration Survey at the National Wind Technology Center: April 2010. Golden, CO: National Renewable Energy Laboratory. NREL/SR-1900-70460.

https://www.nrel.gov/docs/fy18osti/70460.pdf.

NREL is a national laboratory of the U.S. Department of Energy Office of Energy Efficiency \& Renewable Energy Operated by the Alliance for Sustainable Energy, LLC

This report is available at no cost from the National Renewable Energy Laboratory (NREL) at www.nrel.gov/publications.

National Renewable Energy Laboratory 15013 Denver West Parkway

Golden, CO 80401

303-275-3000 • www.nrel.gov

\section{Subcontract Report}

NREL/SR-1900-70460

June 2018

Contract No. DE-AC36-08G028308 
This publication was reproduced from the best available copy submitted by the subcontractor and received no editorial review at NREL.

\section{NOTICE}

This work was authored by the National Renewable Energy Laboratory, operated by Alliance for Sustainable Energy, LLC, for the U.S. Department of Energy (DOE) under Contract No. DE-AC36-08GO28308. Funding provided by the U.S. Department of Energy Office of Energy Efficiency and Renewable Energy. The views expressed in the article do not necessarily represent the views of the DOE or the U.S. Government.

This report is available at no cost from the National Renewable Energy Laboratory (NREL) at www.nrel.gov/publications.

U.S. Department of Energy (DOE) reports produced after 1991 and a growing number of pre-1991 documents are available free via www.OSTI.gov.

Cover Photos by Dennis Schroeder: (left to right) NREL 26173, NREL 18302, NREL 19758, NREL 29642, NREL 19795.

NREL prints on paper that contains recycled content. 


\title{
Final Summary Report April 2010 Fixed Point Raptor Migration Survey at the National Wind Technology Center
}

\author{
Prepared for: \\ National Renewable Energy Laboratory (NREL) \\ NREL Technical Monitor: Brenda Beatty \\ 1617 Cole Boulevard, MS: 1532 \\ Golden, CO 80401-3393 \\ 303-275-3114 \\ September 14, 2011 \\ Revised May 9, 2013 \\ Submitted by: \\ Eco-Logic LLC \\ John A. DuWaldt, Principal Investigator \\ 1484 Belford Court \\ Evergreen, CO 80439 \\ $720-849-1740$ \\ 303 674-1212 (fax) \\ Jduwaldt@evcohs.com
}




\section{TABLE OF CONTENTS}

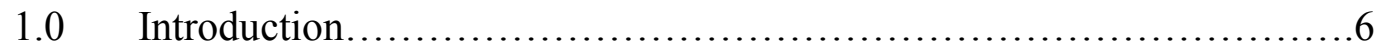

2.0 Background.................................................... 6

3.0 Objectives................................................... 78

4.0 Methods...................................................... 9

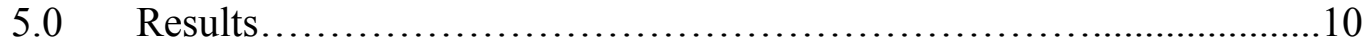

$5.1 \quad$ Analysis of Current Data.....................................11

5.2 Comparison of Current Data and Historical Data.................22

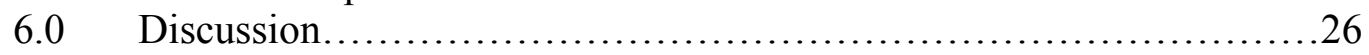

6.1 Resident Raptors Observed on the NWTC in 2010 and 1995_...27

6.2 Migratory Raptors Observed on the NWTC in 2010 and 1995 ..27

6.3 Flight Heights of Raptors in NWTC Airspace..................30

6.4 Duration of Onsite Raptor Visits.............................31

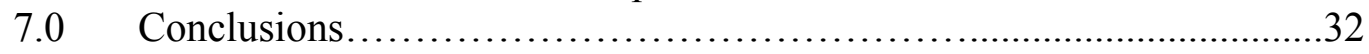

$8.0 \quad$ Recommendations.................................................. 32

$9.0 \quad$ References......................................................... 35 


\section{List of Tables}

Table 5.1 April 2010 Numbers of Raptors by Species Observed At the NWTC, By Date Table 5.2 April 2010 Migrating Raptors Observed Within the NWTC Airspace Table 5.3 April 2010 Resident Raptors Observed within the NWTC Airspace Table 5.4 Comparison of Migrant Raptor Species Observed at NWTC, April 1995 versus April 2010

Table 6.1 Comparisons of spring Migratory Raptor Observations between Years and Sites Table 6.2 Comparison of Observed Raptor Flight Heights in NWTC Airspace to Heights of Onsite Aerial Structures 


\section{List of Figures}

Figure 1.1 National Wind Technology Center Location Map

Figure 5.1 Total Raptor and Vulture (Migrant+Resident) Frequency Ranking for April 2010, NWTC Observations

Figure 5.2 Histogram of NWTC April 2010 Resident Raptor Visit Durations

Figure 5.3 Histogram of Raptor Flight Height in Relation to Structure Height and Number

Figure 5.4 DRRMS Total April and Spring Raptor Count 2004-2010

Figure 5.5 DRRMS Recent Spring and April Migrating Raptors Per

Observation Hour 


\section{List of Acronyms and Abbreviations}

$\begin{array}{ll}\text { BGEPA } & \text { Bald and Golden Eagle Protection Act } \\ \text { BMPs } & \text { Best Management Practices } \\ \text { DOE } & \text { United States Department of Energy } \\ \text { DRRMS } & \text { Dinosaur Ridge Raptor Monitoring Station } \\ \text { EO } & \text { Executive Order } \\ \text { HMANA } & \text { Hawk Migration Association of North America } \\ \text { m } & \text { meters } \\ \text { MBTA } & \text { Migratory Bird Treaty Act } \\ \text { met } & \text { meteorological } \\ \text { min. } & \text { minutes } \\ \text { MOU } & \text { Memorandum of Understanding } \\ \text { NREL } & \text { National Renewable Energy Laboratory } \\ \text { NWTC } & \text { National Wind Technology Center } \\ \text { USFWS } & \text { United States Fish and Wildlife Service } \\ \text { wk } & \text { week }\end{array}$




\subsection{Introduction}

The U.S. Department of Energy's (DOE) National Renewable Energy Laboratory (NREL) conducts a variety of research projects concerning renewable energy technologies at its South Table Mountain headquarters in Golden, Colorado; and wind energy research at the National Wind Technology Center (NWTC) located approximately 8 miles south of Boulder, Colorado, in northern Jefferson County (Figure 1.1). The NWTC provides a location with consistent winds and high speed gusts suitable for testing wind turbine technologies. It is operated by the Alliance for Sustainable Energy LLC for DOE as the premier wind energy research and testing center in the country (DOE, 2002). Currently the NWTC houses a variety of structures on the 114 hectare (290 acre) site, including 13 operating turbines and 24 meteorological (met) towers (personal communication, B. Beatty, 2010). Although there is a relatively small number of turbines at the NWTC compared to many commercial wind farms, the aerial structures at the NWTC pose a potential threat to resident and migratory birds, just as other instrument, telephone, and broadcast towers, and large-scale wind power generation facilities do (Erickson, et al., 2001; Manville, 2005). As a result, to understand the site-specific risks, NREL is currently conducting a yearlong survey of avian and bat use patterns at the NWTC, supplemented by mortality surveys. That study consists of fixed-point avian use surveys, sitewide transects to assess abundance of nesting birds, surveys of springtime migrating raptors, and mortality surveys for birds and bats. This report details the results of a migratory raptor field survey conducted at the NWTC during the month of April, 2010 as part of the larger study of site use by birds, and the site's effects on birds and bats.

\subsection{Background}

Seasonal bird migrations are a world-wide phenomenon affecting a large number of species. In the United States bird species and other vertebrate groups exhibit a variety of distinct migratory habits thought to have developed as a result of seasonal changes in food availability (Newton 2009). The United States Fish and Wildlife Service (USFWS) lists 1,007 of the 2,055 North American bird species residing in the United States as migratory (Federal Register, 2010; Chesser, et al., 2009). A noteworthy portion, and perhaps the best known migrations in North America, is the southward fall and northward spring bird migrations of which the Central Flyway portion of the North American Flyway is a significant part. North American migrants annually fly south to the southern United States, Central America, South America, and the Caribbean to overwinter, returning north to their nesting regions each spring. Colorado's eastern Southern Rocky Mountain front is a linear path that raptors follow in the western portion of the Central Flyway.

Some migratory movements are not obvious because they occur at night. Many songbird species utilize this method and their activity is known to us through the use of detection tools such as radio-tagging, radar, and night lights. Two groups, the diurnal raptors (herein referred to as raptors), Order Falconiformes, and the vultures, Order Ciconiiformes (storks, herons, etc.) Incertae sedis [of uncertain taxonomic placement] are adapted to daytime migratory flights (Newton, 2008; Remsen, et al., 2007). Raptors take advantage of rising sun-warmed air, called thermals, or disjunct topographic highs, such as mountain fronts, that force prevailing winds upward and aid in migratory flight. 


\section{Figure 1.1 NREL National Wind Technology Center Location Map}

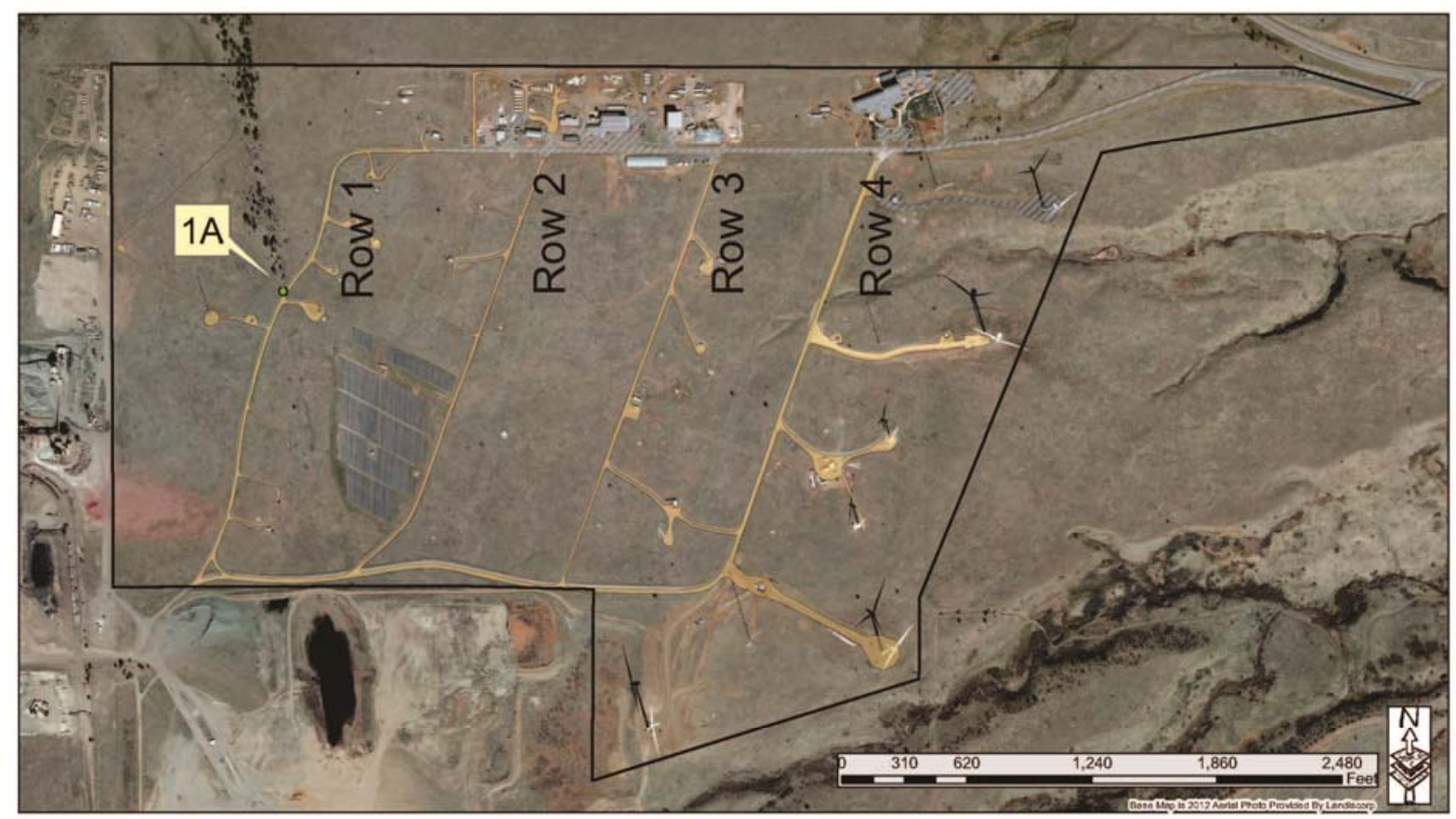

NWTC Raptor Survey Observation Location, 2011

Raptors use spread-wing soaring to gain altitude in currents of rising air, and then glide a distance, gradually losing altitude until they encounter the next thermal to regain gliding height. This technique minimizes energy-depleting flapping, and although rising and gliding is slower than flying by straight-line flapping, it uses only 5 to $25 \%$ of the energy consumed by flapping, reducing the physiological stress of migration, and reducing the number and duration of stopovers for recovery and feeding, which, in turn, reduces predation and other risks (Newton, 2008).

The eastern front of the Southern Rocky Mountains in central Colorado (i.e., the Front Range) is used annually by raptors residing in the intermountain west, particularly for spring migration north from lower latitudes. The eastern mountain front trends north-south and is set-off from the adjacent high plains by a precipitous rise of 3,000 feet in one mile. This juxtaposition of a flat heating surface (the plains) with the mountainous barrier to prevailing winds forms a corridor for raptor migration. It should be noted that a number of raptor species and numerous other bird species exhibit a circular or dual-route migration due to seasonal climatic variation (i.e., wind and storm patterns differ between spring and fall), changes in prey availability, changes between seasons, etc. (Newton 2008, Goodrich and Smith 2008). The result is that a species or group of species migrate south by one route and north using another, or they exhibit different concentration patterns at the migration terminuses. Specifically, when birds initiate migration their numbers often coalesce starting with a broad, diffuse front that tapers from a broader band into a narrow stream. One of the better known examples is the Central America landmass which is utilized as a narrow land route that affords a non-water crossing from North to South America. 
Large water body crossings are very costly to bird species, and many species go to great lengths to avoid them (Newton 2008).

Where geography and/or climate provide thermals for raptors, as along the Front Range, dramatic concentrations of raptors occur in the spring as they use the consistent, moving air masses to gain altitude for gliding (Newton 2008). The Colorado Front Range exhibits spring thermals favorable to efficient northward flight that is not duplicated in the fall. In addition, the fall migration organizes as a broad front of individuals and family groups coalescing into a concentrated stream south of the northern/rocky mountain states. Similarly, the northern return flow through Colorado reflects the overlapping of individual flight paths south of Colorado so that favorable daily thermals can be utilized to conserve body fat as birds near their summer breeding areas.

\subsection{Objectives}

Wind turbines, antenna, and Met towers are known sources of bird collisions and fatalities (Manville, 2005; Erickson 2001). Although the NWTC is a research facility, and not a commercial wind farm, there are a number of aerial structures present onsite that may pose a risk to birds, including migrating and resident raptors. Monahan (1996) conducted an initial raptor occurrence study during 1994-1995 to determine species presence and use of the facility. Monahan's team recorded 786 diurnal raptors over a 17 month period, concluding that species using NWTC habitat were few in number and any collisions with structures or equipment would not affect regional populations. A second study conducted in 2002, compared onsite and offsite habitat use by avian species (Schmidt et al., 2003). Schmidt et al. recorded 212 raptor occurrences on and near the NWTC during a year-long study. Winter abundance was found to exceed summer abundance at the site, which follows the raptor abundance trend for the Boulder Valley as a whole (Berry and Bock 1998). Two species, the American kestrel (Falco sparverius) and the red-tailed hawk (Buteo jamaicensis), were observed most often at the NWTC during the 2002 study. The study concluded that raptors are slightly more abundant at the NWTC during winter, and show a slight preference for perch structures at the site compared to structures on the surrounding landscape. Some evidence of raptor mortality at the NWTC was observed during the 2002 study (six bird carcasses were recovered during mortality searches in 2001 and 2002, including one American kestrel). In addition, the 2002 Sitewide EA reported a rough-legged hawk fatality. Since that time, NREL ESH staff reports that the remains of two great horned owls (2008 and 2010) and one red-tailed hawk (2008) were found on the NWTC near met towers in the western portion of the site (personal communication, B. Beatty 2010). Schmidt et al. estimated that approximately 24 avian fatalities per year may occur at the NWTC, but very few would be raptors.

The objective of the current study was to gain further understanding of raptor use of the NWTC during spring migration, and to compare the results to data collected in 1994-95 and 2002. This was accomplished by diurnal observation of raptor movement in and around the NWTC during the month of April, 2010 when raptor migration along Colorado's Front Range peaks (Hawk Migration Association of North America [HMANA] 2010). Observations made during April 2010 provide information on total numbers, species composition, flying times, heights, and directions. In addition, the NWTC observations are compared to the migrant raptor population observed at the Dinosaur Ridge Raptor Monitoring Station (DRRMS), an annual ornithological monitoring station located 8 miles south of the NWTC. 


\subsection{Methods}

The primary method applied to this study of migratory raptors was a fixed-point survey, a technique where recurring, daily observations are made from the same location (Erickson, et al., 2007). The observer employed standard $8 \times 50$ binoculars and a $60 \mathrm{X}$ zoom spotting scope to make identifications at distance. The observation point, designated observation point $1 \mathrm{~A}$ as shown in Figure 1.1, was located in the northwestern corner of the NWTC between Schmidt's (2003) observation points Number 1 and 2. This location has GPS-defined latitude and longitude coordinates:

\section{$\mathrm{N}: 39^{\circ} 54.658$ ' \\ W: $-105^{\circ} 14.008$,}

Observations to locate raptors were conducted Monday through Friday from April $5^{\text {th }}$ through April $30^{\text {th }}, 2010$. Daily observations were conducted for five hour periods during the hours of 0900 through 1400. This time-frame coincides with daytime air heating and the development of thermals necessary for raptor migratory flights. Daily raptor migration behavior in temperate latitudes consists of morning roosting until air temperatures increase enough to create rising air thermals sufficient for soaring. The majority of daily soaring and gliding trails off in midafternoon when vertical air movement begins to decrease (Newton, 2008; HMANA, 2010).

April raptor observations were conducted only during weekdays, Monday through Friday. The effect of weekday-only observations is an undercounting of spring raptors migrating past the NWTC. A simple undercounting assumption is that $6 / 20^{\text {th }}$ or $30 \%$ of the weekly raptor passage was not observed due to no weekend counts [six weekend days or six twentieths of the study periods occurred during the four weekends in the month of April 2010]. The April 2010 average migratory raptor/hour passage observed at the nearby DRRMS was 3.1 raptors/hour on weekdays and 9.7 raptors/hour on weekend days (HMANA 2010). The highest daily April raptor count was Saturday April 10, when DRRMS recorded 98 raptors, or 22\% of the total April tally. The large weekend percentage for the monthly tally for April 2010 suggests that a significant number of raptors observable from the NWTC were not tallied due to the survey schedule. A review of six previous years of DRRMS data from 2004 to 2009 shows that for each year the two days with highest April tallies account for 19\%, 19\%, and 32\% of the monthly total. For 2009 the three days of highest values equaled $52 \%$ of the month's observed migrants. These percentages suggest that missing a single day of the April migration could have a large effect on the monthly total. This difference is likely due to weather-mediated fluctuations in daily movement. Therefore a $30 \%$ correction is applied to the total hawk count estimate for the NWTC, yielding an estimate of 491 total raptor passing the site in April 2010.

Raptor migration observations were tabulated hourly on standard data sheets. Information collected included species, number observed, height, direction and distance from observer, as well as weather conditions. Instances of raptors passing over or within NWTC air space were mapped on 7.5 minute topographic quadrangle reproductions tied to field data notes. Migrant raptors were distinguished from non-migrants as those exhibiting south to north flight, especially when combined with locations west of the NWTC and/or above or west of the mountain front. Field observations were transferred to the NREL natural resource database as Microsoft ${ }^{\circledR}$ Excel 
spreadsheets. Original field sheets were transferred to the NREL technical monitor as one of the project deliverables.

\subsection{Results}

April 2010 raptor observations at the NWTC recorded both migratory and resident raptors. Table 5.1 shows the total daily raptor occurrence by date and species abundance.

\subsection{Analysis of Current Data}

Migratory and resident raptors and vultures were observed for 20 consecutive weekdays from April 5 to 30, 2010 to gain information on migratory visits to, over, or near the NWTC. In addition, this information was compared to raptor migration observations collected during the same time period at the DRRMS, a nearby monitoring post (eight miles south of the NWTC) that records the spring migration of raptors that pass south to north along the eastern edge of the Front Range.

During 20 days of 0900 to 1400 "mid-day" observations at the NWTC a total of 378 observations of 10 different raptor species were recorded (Table 5.1). This included 73 raptors that could not be identified to species (sum of three unidentified genera: Accipiter, Buteo, and Falco ), and 24 that could not be identified to genus (i.e., Unidentified Raptor). The unidentified raptors result from observations made during poor lighting and/or at distances that precluded species silhouette recognition. Typically this class of observations consists of migratory birds that occurred over the mountain front two miles west of the NWTC. An average of 18.9 or 19 raptor observations per day were recorded from the NWTC, with a range of 3 to 42 . It should be noted that this average includes both migratory and resident raptors. Resident raptors often made multiple appearances daily, particularly a pair of American kestrels and two pair of red-tailed hawks. Species frequency ranking for April 2010 NWTC observations is shown in Figure 5.1. The most abundant species observed was the turkey vulture (114 observations), followed by the American kestrel (85), and red-tailed hawk (65). Seven species were observed fewer than 10 times: golden eagle (7), osprey (3), bald eagle (2), Cooper's hawk (2), sharp-shinned hawk (1), prairie falcon (1), and merlin (1). 
Table 5.1 April 2010 Numbers of Raptors by Species Observed At the NWTC, By Date (includes both Migrating and Resident Raptors)

\begin{tabular}{|c|c|c|c|c|c|c|c|c|c|c|c|c|c|c|c|c|c|c|c|c|c|}
\hline Species & 05 & 06 & 07 & 08 & 09 & 12 & 13 & 14 & 15 & 16 & 19 & 20 & 21 & 22 & 23 & 26 & 27 & 28 & 29 & 30 & Total \\
\hline $\begin{array}{l}\text { Turkey } \\
\text { Vulture }\end{array}$ & 23 & 2 & 35 & 7 & 5 & & 2 & 1 & 7 & 7 & 4 & 1 & 11 & 1 & & 4 & 2 & & 2 & & 114 \\
\hline Osprey & & & & & & & & & & & & & & & & 1 & & & & 2 & 3 \\
\hline Bald Eagle & & & & & & & & & & 1 & 1 & & & & & & & & & & 2 \\
\hline $\begin{array}{c}\text { Northern } \\
\text { Harrier }\end{array}$ & & & & & & & & & & & & & & & & & & & & & 0 \\
\hline $\begin{array}{c}\text { Sharp- } \\
\text { shinned } \\
\text { Hawk }\end{array}$ & & & & & & & & & & & & & & & & & 1 & & & & 1 \\
\hline $\begin{array}{c}\text { Cooper's } \\
\text { Hawk }\end{array}$ & & & & & & & & & 1 & & & 1 & & & & & & & & & 2 \\
\hline $\begin{array}{l}\text { Northern } \\
\text { Goshawk }\end{array}$ & & & & & & & & & & & & & & & & & & & & & 0 \\
\hline $\begin{array}{c}\text { Broad- } \\
\text { winged } \\
\text { Hawk }\end{array}$ & & & & & & & & & & & & & & & & & & & & & 0 \\
\hline $\begin{array}{c}\text { Red-tailed } \\
\text { Hawk }\end{array}$ & 5 & 1 & & 7 & 6 & 4 & 1 & 3 & 5 & 5 & 1 & & 3 & 4 & 1 & 3 & 10 & & 5 & 1 & 65 \\
\hline $\begin{array}{c}\text { Swainson's } \\
\text { Hawk }\end{array}$ & & & & & & & & & & & & & & & & & & & & & 0 \\
\hline $\begin{array}{c}\text { Ferruginous } \\
\text { Hawk }\end{array}$ & & & & & & & & & & & & & & & & & & & & & 0 \\
\hline $\begin{array}{c}\text { Golden } \\
\text { Eagle }\end{array}$ & 1 & & & & 1 & 1 & & & & & 1 & & 1 & 1 & & 1 & & & & & 7 \\
\hline $\begin{array}{c}\text { American } \\
\text { Kestrel }\end{array}$ & & 2 & 1 & 6 & 6 & 5 & 4 & 1 & 2 & 6 & 11 & 11 & 2 & 4 & 1 & 6 & 4 & 3 & 5 & 5 & 85 \\
\hline Merlin & & & & & & & & & & & & & & 1 & & & & & & & 1 \\
\hline $\begin{array}{c}\text { Peregrine } \\
\text { Falcon }\end{array}$ & & & & & & & & & & & & & & & & & & & & & 0 \\
\hline $\begin{array}{l}\text { Prairie } \\
\text { Falcon }\end{array}$ & & & & & & & & & & & & & 1 & & & & & & & & 1 \\
\hline $\begin{array}{c}\text { Unidentified } \\
\text { Accipiter }\end{array}$ & & & & & 1 & & & & & & & & & 1 & & & & & & & 2 \\
\hline $\begin{array}{c}\text { Unidentified } \\
\text { Buteo }\end{array}$ & 4 & 2 & 4 & 4 & 4 & 2 & & 16 & 7 & 2 & 3 & & 3 & & & 7 & 1 & & 1 & 3 & 63 \\
\hline $\begin{array}{c}\text { Unidentified } \\
\text { Falco }\end{array}$ & 2 & & 1 & 1 & 1 & & & & & & & & & & & 3 & & & & & 8 \\
\hline $\begin{array}{l}\text { Unidentified } \\
\text { Eagle }\end{array}$ & & & & & & & & & & & & & & & & & & & & & 0 \\
\hline $\begin{array}{c}\text { Unidentified } \\
\text { Raptor }\end{array}$ & 2 & & 1 & 2 & 2 & 5 & 2 & 2 & 3 & & 4 & & & & 1 & & & & & & 24 \\
\hline $\begin{array}{c}\text { Total By } \\
\text { Date }\end{array}$ & 37 & 7 & 42 & 27 & 26 & 17 & 9 & 23 & 25 & 21 & 24 & 13 & 22 & 12 & 3 & 25 & 18 & 3 & 13 & 11 & 378 \\
\hline & & & & & & & & & & & & & & & & & & & & & \\
\hline
\end{tabular}




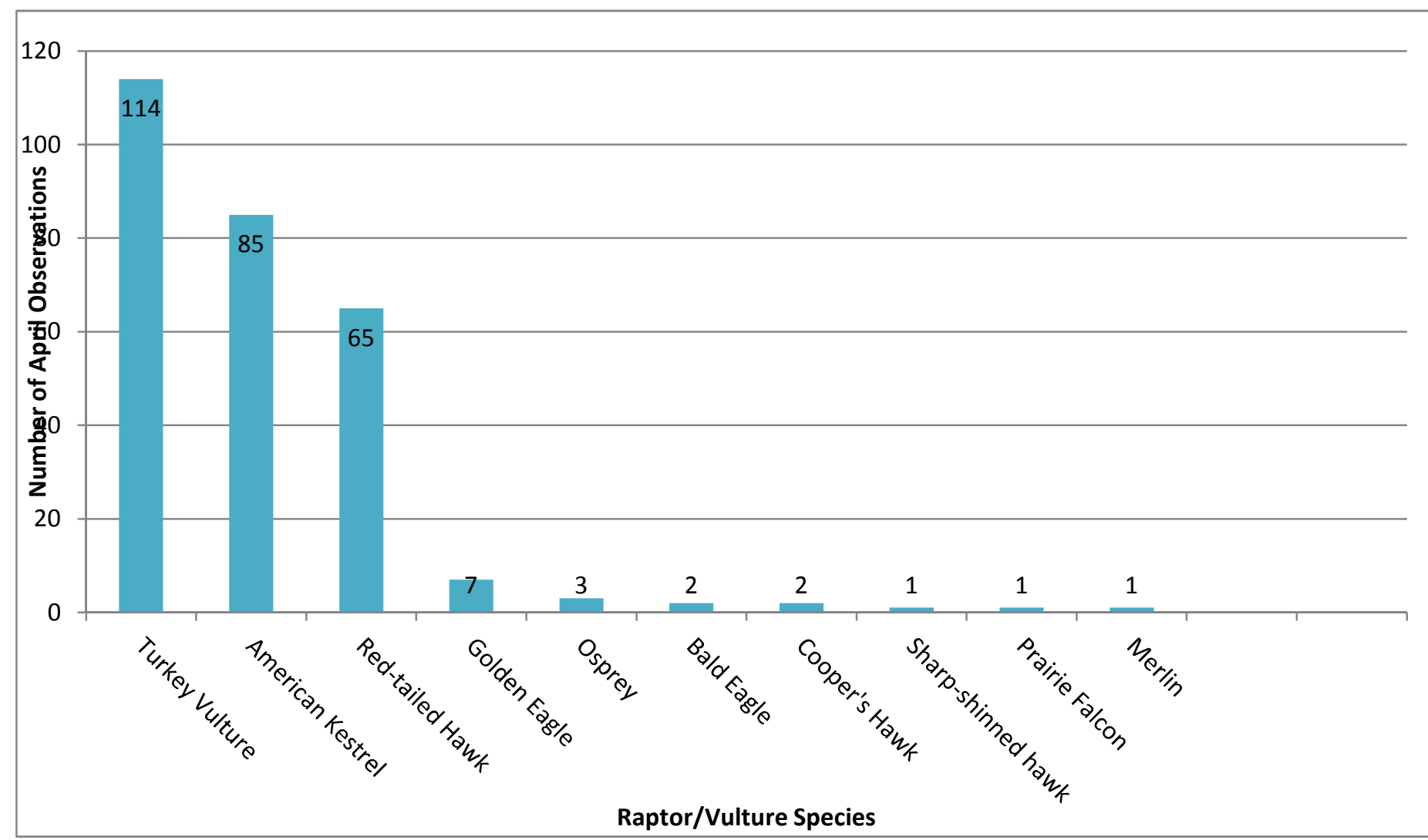

\section{Figure 5.1 Total Raptor and Vulture (Migrant+Resident) Frequency Ranking for April 2010 NWTC Observations}

Thirty- four percent of identified raptors observed (127 of 378) during the study period (i.e., during 95.5 hours of observation, weekdays only) were classified as migrants, an average of 6.5 per day with a range of 1 to 40. Of the 10 species observed, the most abundant migrant observed from the fixed-point study location was the turkey vulture (114), followed by the red-tailed hawk (10), golden eagle (3), osprey (2), and one each: sharp-shinned hawk, Cooper's hawk, merlin, prairie falcon, and bald eagle. In addition 97 unidentified raptor migrants were observed including: unidentified Buteo (32), unidentified raptor (10), unidentified Accipiter (2), and unidentified Falco (2). The unidentified species component of migrant observations is equal to $36.5 \%$ of all migrants observed. This contrasts with the unidentified portion of resident raptor observations, which represents only $20 \%$ of total non-migrant observations. The difference in these percentages is reasonable given that most of the April 2010 migrant raptors flew along the top of the mountain front to the west, at a substantially greater distance from the NWTC than most observed non-migrants and thus presented on average, a smaller, less resolvable image. During the same time period, DRRMS recorded 437 raptors representing 17 species during 105.5 hours of observation, including weekends (HMANA 2010). 
During April observations five migrant raptors entered the NWTC airspace during four observation events (i.e., three individuals and one pair). These occurrences are listed in Table 5.2 with presence data including date, time of day, location, heights, behavior and duration. These five raptors represent three percent of the migratory raptors observed during the April survey; therefore $97 \%$ of observed migrating raptors (during this single season) were seen outside of the NWTC airspace and did not enter NWTC airspace (this does not account for migrants passing through the NWTC airspace on weekends). In 2010, the stream of migrating raptors tended to be west of the NWTC, this varies by year. The frequency of migrant passages through NWTC airspace in April 2010 averaged 1/week (wk) with an average duration of 4.25 minutes (min.). Flight height of these migrants ranged from zero to $250 \mathrm{~m}$.

Table 5.2 April 2010 Migrating Raptors Observed Within the NWTC Airspace

\begin{tabular}{|l|l|l|l|l|}
\hline DATE & SPECIES & $\begin{array}{l}\text { TIME } \\
\text { (Duration) }\end{array}$ & HEIGHT & $\begin{array}{l}\text { LOCATION and } \\
\text { BEHAVIOR }\end{array}$ \\
\hline \hline $4 / 9 / 10$ & $\begin{array}{l}\text { Unknown } \\
\text { raptor }\end{array}$ & $\begin{array}{l}1220-1222 \\
(2 \text { min. })\end{array}$ & 250 meters & $\begin{array}{l}\text { Gliding north to } \\
\text { south over site }\end{array}$ \\
\hline $4 / 15 / 10$ & $\begin{array}{l}\text { Coopers } \\
\text { Hawk }\end{array}$ & $\begin{array}{l}0900-0910 \\
(10 \text { min. })\end{array}$ & $\begin{array}{l}0-20 \\
\text { meters }\end{array}$ & $\begin{array}{l}\text { Perched in } \\
\text { Ponderosa Pine on } \\
\text { NW corner of site; } \\
\text { flies to LaFarge } \\
\text { property and dives } \\
\text { on passerines }\end{array}$ \\
\hline $4 / 22 / 10$ & Merlin & $\begin{array}{l}1148-1149 \\
(1 \text { min. })\end{array}$ & 60 meters & $\begin{array}{l}\text { Crossed W edge } \\
\text { of site flying south } \\
\text { to north }\end{array}$ \\
\hline $4 / 30 / 10$ & Osprey(pair) & $\begin{array}{l}1116-1118 \\
(2 \text { min. })\end{array}$ & 100 meters & $\begin{array}{l}\text { Flying SE to NW } \\
\text { over northern third } \\
\text { of site. Flew } \\
\text { within 70 meters } \\
\text { of Site 4.0 turbine } \\
\text { rotor sweep }\end{array}$ \\
\hline
\end{tabular}

The migrant raptors observed within the NWTC airspace included: one unknown raptor on April 9; one Coopers hawk on April 15; one merlin on April 22; and a pair of osprey on April 30. Four of these five birds crossed the NWTC at altitudes ranging from 60 to 250 meters $(\mathrm{m})$. Flight durations within the NWTC airspace ranged from one to two minutes. The April 15 visit by a Cooper's hawk was the longest and lowest onsite visit by a migrating raptor, lasting 10 minutes and at heights ranging from 0 to 20 meters. This individual perched on a tree in the pine ridge at the northwest corner of the site, then flew to the adjacent LaFarge property west of the NWTC western boundary and dove on passerines (i.e., perching birds, or songbirds). This individual was the only migratory raptor observed hunting or perching on the NWTC in April 2010. Onsite visits and hunting activities vary by year, depending on weather and wind patterns. The pair of osprey was observed flying within 70 meters of the utility-scale turbine at site 4.0. 
During April 2010 DRRMS observers tallied four bald eagles, seven golden eagles, and two peregrine falcons in migration over the I-70/Morrison Hogback viewing station (HMANA 2010). Only half of these DRRMS observations occurred on days when the investigator for this study was onsite at the NWTC, and none of these migratory birds were observed. However, as discussed below, resident golden eagles and bald eagles were observed near the NWTC during the April 2010 survey.

In contrast to the transient individuals shown in Table 5.2 and discussed above, three pairs of resident raptors: one pair of American kestrels and two pairs of red-tailed hawks, made frequent visits to the NWTC to perch, mate, and hunt. In addition, local turkey vultures periodically flew over the site. Seven other unidentified raptors made one to two minute passages of the site, and could likely have been the abovementioned residents observed in unfavorable light or other identification limiting conditions. Table 5.3 lists these occurrences along with visit duration, height, location, and behavior.

In addition to the near-site nesting raptors discussed above, bald eagles, golden eagles, and peregrine falcons were observed and are known to occur in the vicinity of the NWTC during the breeding season (Monahan 1996). Monahan (1996) observed all three species in the Eldorado Canyon area within 2.5 miles of the NWTC. Fifteen bald eagle and 13 golden eagle transits of the site were also observed by Monahan (1996) during a 17-month survey, although none of the bald eagle observations occurred during the April 1995 portion of the study. Monahan was unable to establish actual numbers of eagles in the vicinity of the NWTC, however two winter afternoon roosting surveys at Eldorado Canyon observed eight and 18 eagles in 1995. During April 2010 two bald eagles were observed in flight north of the NWTC, and a pair of bald eagles was observed nesting in a plains cottonwood stand in the Coal Creek drainage channel approximately 2.5 miles northeast of the NWTC. The Coal Creek nesting pair were observed only from offsite locations and did not approach the NWTC during April observation periods. Local ornithologists report five breeding bald eagle pairs existed in Boulder County during 20082010 surveys, including the Coal Creek pair (Hallock and Jones 2011). A nesting pair also exists nearby at Standley Lake, in Jefferson County. Local authorities also report from three to five breeding pairs of peregrine falcons currently in the county (Hallock and Jones 2011).

Table 5.3 April 2010 Resident Raptors Observed Within the NWTC Airspace

\begin{tabular}{|l|l|l|l|l|}
\hline DATE & SPECIES & $\begin{array}{l}\text { TIME } \\
\text { (Duration) }\end{array}$ & $\begin{array}{l}\text { HEIGHT } \\
\text { (Meters) }\end{array}$ & $\begin{array}{l}\text { LOCATION } \\
\text { and } \\
\text { BEHAVIOR }\end{array}$ \\
\hline $4 / 05 / 10$ & $\begin{array}{l}\text { Red-tailed } \\
\text { Hawk }\end{array}$ & $\begin{array}{l}1025-1042 \\
(17 \mathrm{~min} .)\end{array}$ & 80 & $\begin{array}{l}\text { Roosting on } \\
\text { MET tower }\end{array}$ \\
\hline "“ & " & $\begin{array}{l}1051--1055 \\
(4 \mathrm{~min} .)\end{array}$ & 80 & $\begin{array}{l}\text { Top of MET } \\
\text { tower }\end{array}$ \\
\hline "، & $\begin{array}{l}\text { Turkey } \\
\text { Vulture }\end{array}$ & $\begin{array}{l}\text { (4min.) } \\
\text { (121-1125 }\end{array}$ & 50 & $\begin{array}{l}\text { Flying across } \\
\text { south edge of } \\
\text { site }\end{array}$ \\
\hline "“ & Unknown & $1110-1111$ & 120 & Flying across \\
\hline
\end{tabular}




\begin{tabular}{|c|c|c|c|c|}
\hline & Falco & (1min.) & & $\begin{array}{l}\text { northern half } \\
\text { of site }\end{array}$ \\
\hline " " $"$ & $\begin{array}{l}\text { Red-tailed } \\
\text { Hawk }\end{array}$ & $\begin{array}{l}1250-1307 \\
\text { (17min.) }\end{array}$ & 80 & $\begin{array}{l}\text { Flies to met } \\
\text { tower perch; } \\
\text { joined by } \\
\text { mate; copulate }\end{array}$ \\
\hline $4 / 05 / 10$ & $\begin{array}{l}\text { Unknown } \\
\text { Falco }\end{array}$ & 1334(1min.) & 240 & $\begin{array}{l}\text { Fast glide } \\
\text { south to north } \\
\text { across site }\end{array}$ \\
\hline $4 / 06 / 10$ & $\begin{array}{l}\text { American } \\
\text { Kestrel }\end{array}$ & 0910(1min.) & Unknown & $\begin{array}{l}\text { Blown across } \\
\text { site }\end{array}$ \\
\hline " & $\begin{array}{l}\text { Red-tailed } \\
\text { Hawk }\end{array}$ & $\begin{array}{l}1125-1127 \\
\text { (2min.) }\end{array}$ & 10 & $\begin{array}{l}\text { Hunting low } \\
\text { on } \mathrm{N} \text { edge of } \\
\text { site }\end{array}$ \\
\hline “ & $\begin{array}{l}\text { Turkey } \\
\text { Vulture }\end{array}$ & 1130 (1min.) & 20 & $\begin{array}{l}\text { Flying along } \\
\text { E edge of site }\end{array}$ \\
\hline $4 / 06 / 10$ & $\begin{array}{l}\text { American } \\
\text { Kestrel }\end{array}$ & 1220 (1min.) & 60 & $\begin{array}{l}\text { Blown across } \\
\text { site SW to NE }\end{array}$ \\
\hline $4 / 07 / 10$ & $\begin{array}{l}\text { American } \\
\text { Kestrel }\end{array}$ & $\begin{array}{l}0940-1000 \\
\text { (20min.) }\end{array}$ & $10-20$ & $\begin{array}{l}\text { Perch on pole; } \\
\text { flies to MET } \\
\text { tower } \\
\text { guywire; } \\
\text { copulates; } \\
\text { preens }\end{array}$ \\
\hline $4 / 08 / 10$ & $\begin{array}{l}\text { American } \\
\text { Kestrel }\end{array}$ & $\begin{array}{l}\text { 0917-0921 } \\
(4 \mathrm{~min} .)\end{array}$ & $20-60$ & $\begin{array}{l}\text { Perched on } \\
\text { guy wire }\end{array}$ \\
\hline " & $\begin{array}{l}\text { American } \\
\text { Kestrel }\end{array}$ & $\begin{array}{l}0954-0956 \\
\text { (2min.) }\end{array}$ & $20-40$ & $\begin{array}{l}\text { Flies over } \\
\text { central portion } \\
\text { of site }\end{array}$ \\
\hline “ & $\begin{array}{l}\text { Red-tailed } \\
\text { Hawk }\end{array}$ & $\begin{array}{l}\text { 1039-1111 } \\
\text { (32min.) }\end{array}$ & $100-150$ & $\begin{array}{l}\text { Perched on } \\
\text { top of MET-2 } \\
\text { tower }\end{array}$ \\
\hline " & $\begin{array}{l}\text { Red-tailed } \\
\text { Hawk }\end{array}$ & $\begin{array}{l}1052-1053 \\
\text { (1min.) }\end{array}$ & 25 & $\begin{array}{l}\text { Soaring east } \\
\text { side of site }\end{array}$ \\
\hline "“ & $\begin{array}{l}\text { American } \\
\text { Kestrel }\end{array}$ & $\begin{array}{l}1139-1242 \\
\text { (3min.) }\end{array}$ & 10 & $\begin{array}{l}\text { Flies in along } \\
\text { S edge of site; } \\
\text { perches } \\
\text { guywire with } \\
\text { mate }\end{array}$ \\
\hline " & $\begin{array}{l}\text { American } \\
\text { Kestrel }\end{array}$ & 1140 (1min.) & $0-10$ & Attempted kill \\
\hline “" & $\begin{array}{l}\text { Turkey } \\
\text { Vulture }\end{array}$ & $\begin{array}{l}1202-1204 \\
\text { (2min.) }\end{array}$ & 320 & $\begin{array}{l}\text { Soaring across } \\
\text { site }\end{array}$ \\
\hline $4 / 08 / 10$ & $\begin{array}{l}\text { Red-tailed } \\
\text { Hawk }\end{array}$ & $\begin{array}{l}1202-1204 \\
\text { (2min.) }\end{array}$ & 100 & $\begin{array}{l}\text { Same as } \\
\text { above }\end{array}$ \\
\hline $4 / 09 / 10$ & American & $0937-1025$ & 30 & Perched pair \\
\hline
\end{tabular}




\begin{tabular}{|c|c|c|c|c|}
\hline & Kestrel & (48min.) & & $\begin{array}{l}\text { on MET-2 } \\
\text { tower } \\
\text { arms/guywires }\end{array}$ \\
\hline " " $"$ & $\begin{array}{l}\text { American } \\
\text { Kestrel }\end{array}$ & $\begin{array}{l}1025-1058 \\
\text { (33min.) }\end{array}$ & $3-30$ & $\begin{array}{l}\text { Pair perched } \\
\text { on telephone } \\
\text { pole; female } \\
\text { hunts SW } \\
\text { corner of site }\end{array}$ \\
\hline “ & " $" ~$ & $1136(1 \mathrm{~min})$. & 20 & $\begin{array}{l}\text { Fast flight } \\
\text { across site }\end{array}$ \\
\hline "“ & $\begin{array}{l}\text { Red-tailed } \\
\text { Hawk }\end{array}$ & $\begin{array}{l}1305-1310 \\
\text { (5min.) }\end{array}$ & 80 & $\begin{array}{l}\text { Perched on } \\
\text { MET-2 tower }\end{array}$ \\
\hline " & " & 1310 (1min.) & 120 & $\begin{array}{l}\text { Glides across } \\
\text { site }\end{array}$ \\
\hline $4 / 12 / 10$ & $\begin{array}{l}\text { Red-tailed } \\
\text { Hawk }\end{array}$ & $\begin{array}{l}1012-1022 \\
\text { (10min.) }\end{array}$ & 10 & $\begin{array}{l}\text { Perched in } \\
\text { pine ridge }\end{array}$ \\
\hline " & $\begin{array}{l}\text { American } \\
\text { Kestrel }\end{array}$ & $\begin{array}{l}1033-1100 \\
\text { (27min.) }\end{array}$ & 20 & $\begin{array}{l}\text { Pair on } \\
\text { eastern met } \\
\text { tower guywire }\end{array}$ \\
\hline $4 / 12 / 10$ & " & 1158 (1min.) & 30 & $\begin{array}{l}\text { Transit } \\
\text { through site }\end{array}$ \\
\hline $4 / 13 / 10$ & $\begin{array}{l}\text { American } \\
\text { Kestrel }\end{array}$ & $\begin{array}{l}1107-1121 \\
\text { (14min.) }\end{array}$ & $0-20$ & $\begin{array}{l}\text { Perched on } \\
\text { guywire }\end{array}$ \\
\hline $4 / 13 / 10$ & & $\begin{array}{l}1345-1347 \\
\text { (2min.) }\end{array}$ & 10 & $\begin{array}{l}\text { Flight across } \\
\text { site }\end{array}$ \\
\hline $4 / 14 / 10$ & $\begin{array}{l}\text { American } \\
\text { Kestrel }\end{array}$ & $\begin{array}{l}1056-1058 \\
\text { (2min.) }\end{array}$ & $10-20$ & $\begin{array}{l}\text { Hunting hover } \\
\text { SW corner of } \\
\text { site }\end{array}$ \\
\hline $4 / 15 / 10$ & $\begin{array}{l}\text { Turkey } \\
\text { Vulture }\end{array}$ & 1032 (1min.) & 50 & $\begin{array}{l}\text { Soaring along } \\
\text { S border of } \\
\text { site }\end{array}$ \\
\hline $4 / 16 / 10$ & $\begin{array}{l}\text { Red-tailed } \\
\text { Hawk }\end{array}$ & $\begin{array}{l}\text { 0900-0930 } \\
\text { (30min.) }\end{array}$ & 80 & $\begin{array}{l}\text { Perch on top } \\
\text { of MET-2 } \\
\text { tower }\end{array}$ \\
\hline & $\begin{array}{l}\text { American } \\
\text { Kestrel }\end{array}$ & $\begin{array}{l}1040-1049 \\
\text { (9min.) }\end{array}$ & $15-50$ & $\begin{array}{l}\text { Flies S half of } \\
\text { site and } \\
\text { perches on } \\
\text { telephone pole }\end{array}$ \\
\hline " & $\begin{array}{l}\text { Red-tailed } \\
\text { Hawk }\end{array}$ & $\begin{array}{l}1305-1330 \\
\text { (25min.) }\end{array}$ & $0-30$ & $\begin{array}{l}\text { Perched on } \\
\text { MET-2 tower, } \\
\text { also observed } \\
\text { on LaFarge } \\
\text { water tower } \\
\text { and SW cell } \\
\text { tower }\end{array}$ \\
\hline "“ & “6 & $1332-1336$ & 60 & Soaring SW \\
\hline
\end{tabular}




\begin{tabular}{|c|c|c|c|c|}
\hline & & (4min.) & & corner of site \\
\hline “" & $\begin{array}{l}\text { American } \\
\text { Kestrel }\end{array}$ & 1310 (1min.) & 5 & $\begin{array}{l}\text { Perched on } \\
\text { NE side met } \\
\text { tower } \\
\text { guywire; } \\
\text { joined by } \\
\text { mate, fly off }\end{array}$ \\
\hline $4 / 16 / 10$ & $\begin{array}{l}\text { Red-tailed } \\
\text { Hawk }\end{array}$ & $\begin{array}{l}1342-1347 \\
\text { (3min.) }\end{array}$ & $60-80$ & $\begin{array}{l}\text { Perched on } \\
\text { MET-2 tower; } \\
\text { flies to the } \\
\text { SW }\end{array}$ \\
\hline $4 / 19 / 10$ & $\begin{array}{l}\text { Red-tailed } \\
\text { Hawk }\end{array}$ & \begin{tabular}{|l|}
$1013-1029$ \\
(16min.)
\end{tabular} & 80 & $\begin{array}{l}\text { Perched } \\
\text { MET-2 tower; } \\
\text { sentinel }\end{array}$ \\
\hline " $\quad$ " & $\begin{array}{l}\text { Turkey } \\
\text { Vulture }\end{array}$ & $\begin{array}{l}1138-1141 \\
\text { (3min.) }\end{array}$ & 20 & $\begin{array}{l}\text { Soars west } \\
\text { side of site }\end{array}$ \\
\hline “" & $\begin{array}{l}\text { American } \\
\text { Kestrel }\end{array}$ & $\begin{array}{l}1316-1320 \\
\text { (4min.) }\end{array}$ & 20 & $\begin{array}{l}\text { Pair perched } \\
\text { on MET tower }\end{array}$ \\
\hline " & " " & $\begin{array}{l}1320-1334 \\
\text { (14min.) }\end{array}$ & 25 & $\begin{array}{l}\text { Male } \\
\text { successful } \\
\text { hunt; returns } \\
\text { to female; } \\
\text { conducts } 2^{\text {nd }} \\
\text { hunt } \\
\end{array}$ \\
\hline " $\quad$ " & $\begin{array}{l}\text { Turkey } \\
\text { Vulture }\end{array}$ & 1334(1min.) & 200 & $\begin{array}{l}\begin{array}{l}\text { Soars through } \\
\text { center of site }\end{array} \\
\end{array}$ \\
\hline $4 / 19 / 10$ & $\begin{array}{l}\text { American } \\
\text { Kestrel }\end{array}$ & $\begin{array}{l}1343-1348 \\
(5 \mathrm{~min} .)\end{array}$ & 30 & $\begin{array}{l}\text { Perched on } \\
\text { MET tower } \\
\text { arm; flies to } \\
\text { LaFarge } \\
\text { telephone pole }\end{array}$ \\
\hline $4 / 20 / 10$ & $\begin{array}{l}\text { American } \\
\text { Kestrel }\end{array}$ & $\begin{array}{l}1105-1119 \\
\text { (14min.) }\end{array}$ & 20 & $\begin{array}{l}\text { Perched on E } \\
\text { side MET } \\
\text { tower } \\
\text { guywire; flies } \\
\text { E side of site } \\
\text { and leaves } \\
\end{array}$ \\
\hline " & $\begin{array}{l}\text { American } \\
\text { Kestrel }\end{array}$ & 1250 (1min.) & $5-10$ & Crosses site \\
\hline $4 / 20 / 10$ & $\begin{array}{l}\text { American } \\
\text { Kestrel }\end{array}$ & $\begin{array}{l}1315-1327 \\
\text { (12min.) }\end{array}$ & 15 & $\begin{array}{l}\text { Flew in from } \\
\text { LaFarge area, } \\
\text { then observed } \\
\text { moving } \\
\text { among met } \\
\text { towers on east } \\
\text { side of }\end{array}$ \\
\hline
\end{tabular}




\begin{tabular}{|c|c|c|c|c|}
\hline & & & & $\begin{array}{l}\text { NWTC, } \\
\text { apparently } \\
\text { hunting }\end{array}$ \\
\hline $4 / 21 / 10$ & $\begin{array}{l}\text { Red-tailed } \\
\text { Hawk }\end{array}$ & $\begin{array}{l}1154-1205 \\
\text { (11min.) }\end{array}$ & $2-20$ & $\begin{array}{l}\text { Glides into } \\
\text { SW corner of } \\
\text { site and } \\
\text { captures } \\
\text { sm.mammal; } \\
\text { flies to } \\
\text { telephone pole } \\
\text { and consumes }\end{array}$ \\
\hline " " $"$ & $\begin{array}{l}\text { American } \\
\text { Kestrel }\end{array}$ & $\begin{array}{l}1300-1310 \\
\text { (10min.) }\end{array}$ & 20 & $\begin{array}{l}\text { S edge of site } \\
\text { perched on } \\
\text { power pole }\end{array}$ \\
\hline " $" \quad$ & $\begin{array}{l}\text { Red-tailed } \\
\text { Hawk }\end{array}$ & $\begin{array}{l}1224-1312 \\
\text { (48min.) }\end{array}$ & 80 & $\begin{array}{l}\text { Perched top of } \\
\text { MET-2 tower }\end{array}$ \\
\hline “ & $\begin{array}{l}\text { Turkey } \\
\text { Vulture }\end{array}$ & $\begin{array}{l}1258-1300 \\
\text { (2min.) }\end{array}$ & 40 & $\begin{array}{l}\text { Crosses NW } \\
\text { corner of site }\end{array}$ \\
\hline $4 / 21 / 10$ & $\begin{array}{l}\text { Unknown } \\
\text { Buteo }\end{array}$ & $1322(1 \mathrm{~min})$. & 80 & $\begin{array}{l}\text { Soaring SE } \\
\text { corner of site }\end{array}$ \\
\hline $4 / 22 / 10$ & $\begin{array}{l}\text { American } \\
\text { Kestrel }\end{array}$ & $\begin{array}{l}\text { 1029-1031 } \\
\text { (3min.) }\end{array}$ & 10 & $\begin{array}{l}\text { Hover S edge } \\
\text { of site, } \\
\text { hunting }\end{array}$ \\
\hline “ & $\begin{array}{l}\text { American } \\
\text { Kestrel }\end{array}$ & $\begin{array}{l}1045-1046 \\
\text { (1min.) }\end{array}$ & 40 & $\begin{array}{l}\text { Transit west } \\
\text { boundary of } \\
\text { site }\end{array}$ \\
\hline " $" \quad$ " & $\begin{array}{l}\text { American } \\
\text { Kestrel }\end{array}$ & 1141(1min.) & 10 & $\begin{array}{l}\text { Hover/stoop S } \\
\text { edge of site }\end{array}$ \\
\hline " " $"$ & $\begin{array}{l}\text { Red-tailed } \\
\text { Hawk }\end{array}$ & $\begin{array}{l}1236-1247 \\
\text { (11min.) }\end{array}$ & 80 & $\begin{array}{l}\text { Perch on } \\
\text { MET-2 tower }\end{array}$ \\
\hline $4 / 22 / 10$ & $\begin{array}{l}\text { American } \\
\text { Kestrel }\end{array}$ & $\begin{array}{l}\text { 1340-1343 } \\
\text { (3min.) }\end{array}$ & 20 & $\begin{array}{l}\text { Power line } \\
\text { perch SW } \\
\text { edge of site }\end{array}$ \\
\hline $4 / 23 / 10$ & $\begin{array}{l}\text { Red-tailed } \\
\text { Hawk }\end{array}$ & $\begin{array}{l}\text { 0948-1000 } \\
\text { (12min.) }\end{array}$ & 10 & $\begin{array}{l}\text { Perched in } \\
\text { pine ridge }\end{array}$ \\
\hline & $\begin{array}{l}\text { Unknown } \\
\text { Raptor }\end{array}$ & 0935(1min.) & 10 & $\begin{array}{l}\text { Perched in } \\
\text { dead pine tree }\end{array}$ \\
\hline $4 / 23 / 10$ & $\begin{array}{l}\text { American } \\
\text { Kestrel }\end{array}$ & 1015(1min.) & 2 & $\begin{array}{l}\text { Perched on } \\
\text { mullein S site } \\
\text { boundary }\end{array}$ \\
\hline $4 / 26 / 10$ & $\begin{array}{l}\text { American } \\
\text { Kestrel }\end{array}$ & 0915(1min.) & 20 & $\begin{array}{l}\text { NE portion of } \\
\text { site perched } \\
\text { on met tower }\end{array}$ \\
\hline & $\begin{array}{l}\text { Turkey } \\
\text { Vulture }\end{array}$ & 0925(1min.) & 80 & $\begin{array}{l}\text { Soaring over } \\
\text { W half of site }\end{array}$ \\
\hline & American & 1031-1034 & 20 & Soaring over \\
\hline
\end{tabular}




\begin{tabular}{|c|c|c|c|c|}
\hline & Kestrel & (3min.) & & $\begin{array}{l}\text { central portion } \\
\text { of site }\end{array}$ \\
\hline “ & $\begin{array}{l}\text { Unknown } \\
\text { Falco }\end{array}$ & 1055(1min.) & 40 & $\begin{array}{l}\text { Flies across } \\
\text { NW corner of } \\
\text { site }\end{array}$ \\
\hline " & " " $"$ & $\begin{array}{l}1121-1123 \\
(2 \mathrm{~min} .)\end{array}$ & 100 & $\begin{array}{l}\text { Soaring } \\
\text { overhead at } \\
100+\mathrm{m}\end{array}$ \\
\hline " & $\begin{array}{l}\text { American } \\
\text { Kestrel }\end{array}$ & 1308(1min.) & 20 & $\begin{array}{l}\text { Perched on } \\
\text { guy wire } \\
\text { M1.2 tower }\end{array}$ \\
\hline $4 / 26 / 10$ & $\begin{array}{l}\text { Red-tailed } \\
\text { Hawk }\end{array}$ & $\begin{array}{l}\text { 1330-1333 } \\
\text { (3min.) }\end{array}$ & 30 & $\begin{array}{l}\text { Soaring over } \\
\text { pine ridge }\end{array}$ \\
\hline $4 / 27 / 109$ & $\begin{array}{l}\text { Red-tailed } \\
\text { Hawk }\end{array}$ & $\begin{array}{l}\text { 0907-0923 } \\
\text { (16min.) }\end{array}$ & 80 & $\begin{array}{l}\text { Perched on } \\
\text { M-2 tower }\end{array}$ \\
\hline " & " " $"$ & $\begin{array}{l}1125-1128 \\
(3 \min .)\end{array}$ & 30 & $\begin{array}{l}\text { Flies in from } \\
\text { SW to perch } \\
\text { on M-2 tower }\end{array}$ \\
\hline “ & " $" ~ " ~$ & 1152(1min.) & Unknown & $\begin{array}{l}\text { Gliding SE } \\
\text { corner of site } 3\end{array}$ \\
\hline $4 / 27 / 10$ & " " " & 1235 (1min.) & $60-80$ & $\begin{array}{l}\text { Glides in from } \\
\text { NW, perch on } \\
\text { M-2 tower }\end{array}$ \\
\hline $4 / 28 / 10$ & $\begin{array}{l}\text { American } \\
\text { Kestrel }\end{array}$ & 0915(1min.) & 15 & $\begin{array}{l}\text { Pair on east } \\
\text { side met } \\
\text { station } \\
\text { guywire }\end{array}$ \\
\hline $4 / 29 / 10$ & $\begin{array}{l}\text { American } \\
\text { Kestrel }\end{array}$ & 1030(1min.) & 2 & $\begin{array}{l}\text { Sunning on } \\
\text { mullein site } \\
4.3\end{array}$ \\
\hline “ & $\begin{array}{l}\text { Red-tailed } \\
\text { Hawk }\end{array}$ & $\begin{array}{l}1234-1236 \\
(2 \mathrm{~min} .)\end{array}$ & 10 & $\begin{array}{l}\text { Hunting low } \\
\text { at SE corner } \\
\text { of site }\end{array}$ \\
\hline " & $\begin{array}{l}\text { American } \\
\text { Kestrel }\end{array}$ & $\begin{array}{l}1241-1243 \\
\text { (2min.) }\end{array}$ & 10 & $\begin{array}{l}\text { Flying along } \\
\text { N edge of site }\end{array}$ \\
\hline " & $\begin{array}{l}\text { American } \\
\text { Kestrel }\end{array}$ & $\begin{array}{l}1259-1301 \\
(2 \mathrm{~min} .)\end{array}$ & 30 & $\begin{array}{l}\text { Flies through } \\
\text { structures on } \\
\text { eastern } \\
\text { portion of site }\end{array}$ \\
\hline " & $\begin{array}{l}\text { Red-tailed } \\
\text { Hawk }\end{array}$ & $\begin{array}{l}1313-1321 \\
\text { (8min.) }\end{array}$ & 80 & $\begin{array}{l}\text { Perched on } \\
\text { M-2 tower }\end{array}$ \\
\hline " & $\begin{array}{l}\text { American } \\
\text { Kestrel }\end{array}$ & 1317 (1min.) & 15 & $\begin{array}{l}\text { Hunting NW } \\
\text { corner of site }\end{array}$ \\
\hline " & $\begin{array}{l}\text { Red-tailed } \\
\text { Hawk }\end{array}$ & $\begin{array}{l}\text { 1331-1334 } \\
\text { (3min.) }\end{array}$ & 80 & $\begin{array}{l}\text { Perched on } \\
\text { M-2 tower }\end{array}$ \\
\hline $4 / 29 / 10$ & Red-tailed & 1354-1356 & 80 & Soars over \\
\hline
\end{tabular}




\begin{tabular}{|l|l|l|l|l|}
\hline $4 / 30 / 10$ & Hawk & $(2 \mathrm{~min})$. & & guard house \\
\hline Kestrel & $\begin{array}{l}\text { American } \\
(2 \mathrm{~min} .)\end{array}$ & 15 & $\begin{array}{l}\text { Hover hunting } \\
\text { S of M-2 } \\
\text { tower }\end{array}$ \\
\hline$"$ "w & $\begin{array}{l}\text { American } \\
\text { Kestrel }\end{array}$ & $\begin{array}{l}1340-1346 \\
(6 \mathrm{~min} .)\end{array}$ & 20 & $\begin{array}{l}\text { Hover hunting } \\
\text { over SW } \\
\text { corner of site }\end{array}$ \\
\hline
\end{tabular}

Resident raptors were observed within the NWTC airspace a total of 528 minutes. (8.8 hours) during 20 weekdays in April 2010. This represents 9.2 percent of the 95.5 total hours of raptor observation conducted from Station 1A on the NWTC. A total of 82 resident raptor occurrences were recorded during the 20 five-hour survey periods or an average of 4 visits per day or 0.8 visits per hour. Figure 5.2 shows the time distribution of resident raptor visits at the NWTC; an inverse relationship illustrating that in April 2010, residents made shorter duration visits much more often than long ones. The longest visit intervals were two 48 minute visits, one by an American kestrel, the other by a red-tailed hawk. American kestrels were the most frequent resident visitors to the NWTC, with 38 visits accounting for 40.7 percent of the total resident visitor minutes. Twenty-eight red-tailed hawk visits constituted 54.9 percent of the total resident raptor visit minutes, and in decreasing order the other species time percentages were: turkey vulture 2.8, unknown falcon 0.95, unknown Buteo 0.38, and unknown raptor 0.19.

Flight heights of resident raptors visiting the NWTC are also listed in Table 5.3. Heights range from 0 to $320 \mathrm{~m}$ for the three resident species (American kestrel, red-tailed hawk, and turkey vulture) and three classes of non-specific raptors observed (unknown Falco, unknown Buteo, and unknown raptor). Figure 5.3 is a histogram showing the $40 \mathrm{~m}$-increment flight height classes for raptors compared to the number of towers and guywires within the height class. Figure 5.3 double-counts structures and wires from the 41 to 80 and 81 and greater height classes into the 0 to $40 \mathrm{~m}$ class because the taller classes also overlap the shorter classes (a $50 \mathrm{~m}$ tower occupies space from zero to $40 \mathrm{~m}$ as well as from 41 to $50 \mathrm{~m}$ ). The data show that, during this survey, raptors made twice as many visits at heights $40 \mathrm{~m}$ and under and only one-fifth of the visits at heights $80 \mathrm{~m}$ and greater. The majority of resident raptor flights in NWTC airspace occurred at heights similar to the majority of towers, structures and associated guywires. For this analysis guywires are treated as separate structures because: 1) they are spatially distinct from towers they support by several meters, 2) they are more visually cryptic than tower structures, raising a collision concern, and 3) they were utilized frequently for perching by American kestrels. 

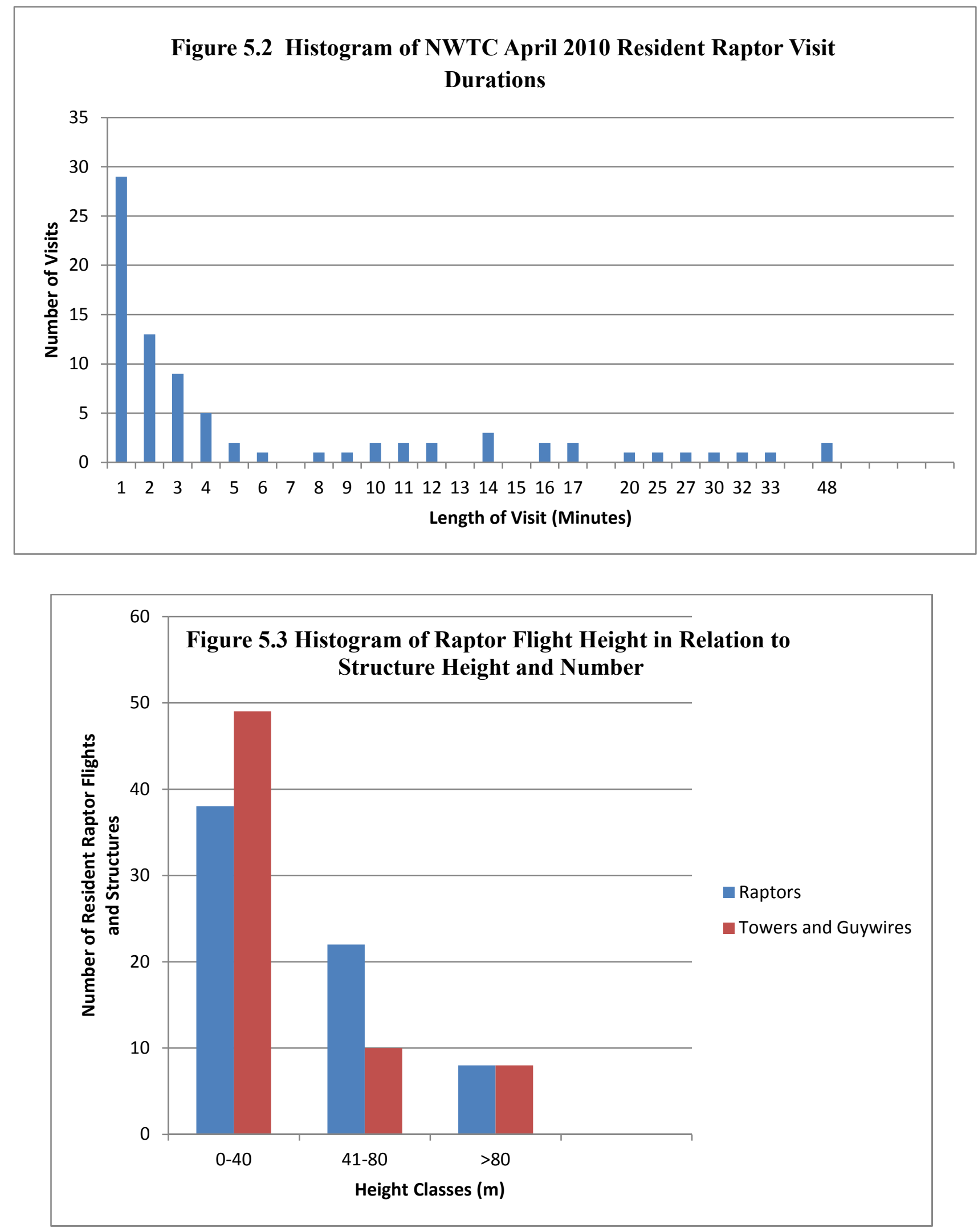


\subsection{Comparison of Current and Historical Data}

Monahan (1996) reports on 140 hours of migratory raptor observations at the NWTC in April 1995 that resulted in 290 observations of 14 raptor species. During the same timeframe the DRRMS recorded 2319 migrant raptors of 17 different species (Monahan 1996). Turkey vultures were the most numerous sighting at the NWTC in 1996, comprising 56\% of April 1995 migratory raptor observations. American kestrels were the second most frequently observed species, equaling 29\% of observed migrants. During the April 2010 NWTC raptor survey a total of 127 migrating raptors representing ten species were observed during 95.5 hours of observation. For the same period DRRMS recorded 437 raptors representing 17 species during 105.45 hours of observation (HMANA 2010). At the DRRMS site, there were also differences in the number of raptors/observation hour in 1995 compared to 2010. In 1995, the raptor frequency was 16.6 raptors/observation hour, while in April 2010, the rate was 4.14 raptors/observation hour. Factors contributing to these variable results are presented in Section 6, Discussion.

Table 5.4 shows the variability between April 1995 and April 2010 NWTC migratory raptor observations by species. The table shows that the turkey vulture is the most abundant migrant raptor during April in both years, and the American kestrel is second in abundance in 1995, but not recorded as a migrant in April 2010. A partial explanation of these results is that $60 \%$ of migrant American kestrels were observed on weekend days at DRRMS in April 2010 when the NWTC observer was not onsite. (Note that Tables 5.1 and 5.4 differ in the number of American kestrels reported for 2010. Table 5.1 reports all members of each species observed [migrants and residents]; whereas Table 5.4 lists only migrants. Residents are individuals who make repeated appearances at the NWTC, thus total numbers of American kestrels in Table 5.4 is a subset of those totaled in Table 5.1.) As listed in Table 5.4, the next most abundant migrant raptors in 1995 were red-tailed hawk, Cooper's hawk, osprey, and unidentified Falco. In 2010 the most abundant species by rank after unidentified Buteos were red-tailed hawk, unidentified raptor, golden eagle, osprey, unidentified Accipiter, and unidentified Falco.

Another source of historical data that demonstrate annual variability is the spring migration record from DRRMS. Internet sources provided the DRRMS spring raptor migration records for six recent years: 2004-2006, and 2008-2010 (HMANA 2010). Figure 5.4 compares the total raptor counts for the season, and raptor counts during the month of April during 2004-2006 and 2008 - 2010. Figure 5.5 compares the number of raptors counted per observation hour for the entire season, and for the month of April, during 2004 - 2006, and 2008 - 2010. Comparing this multi-year information with the 2010 migration allows provides additional data regarding the variability of spring raptor migrations along the Colorado Front Range. 
Table 5.4 Comparison of Migrant Raptor Species Observed at NWTC April 1995 versus April 2010

\begin{tabular}{|c|c|c|}
\hline Species & $\begin{array}{c}\text { April } 1995 \text { Number } \\
\text { Observed }\end{array}$ & $\begin{array}{c}\text { April } 2010 \text { Number } \\
\text { Observed }\end{array}$ \\
\hline Turkey Vulture & 162 & 60 \\
\hline Osprey & 4 & 2 \\
\hline Bald Eagle & 0 & 1 \\
\hline Northern Harrier & 1 & 0 \\
\hline Sharp-shinned Hawk & 1 & 1 \\
\hline Cooper's Hawk & 8 & 1 \\
\hline Northern Goshawk & 3 & 0 \\
\hline Broad-winged Hawk & 2 & 0 \\
\hline Red-tailed Hawk & 9 & 10 \\
\hline Swainson's Hawk & 3 & 0 \\
\hline Ferruginous Hawk & 0 & 0 \\
\hline Golden Eagle & 1 & 4 \\
\hline American Kestrel & 85 & 0 \\
\hline Merlin & 1 & 1 \\
\hline Peregrine Falcon & NL* & 0 \\
\hline Prairie Falcon & 2 & 1 \\
\hline Unidentified Accipiter & 2 & 2 \\
\hline Unidentified Buteo & 3 & 32 \\
\hline Unidentified Falco & 4 & 2 \\
\hline Unidentified Eagle & 1 & 0 \\
\hline Unidentifed Raptor & 0 & 10 \\
\hline Total Migants & 290 & 127 \\
\hline Total Migrants/Observation Hour & 2.07 & 1.27 \\
\hline
\end{tabular}




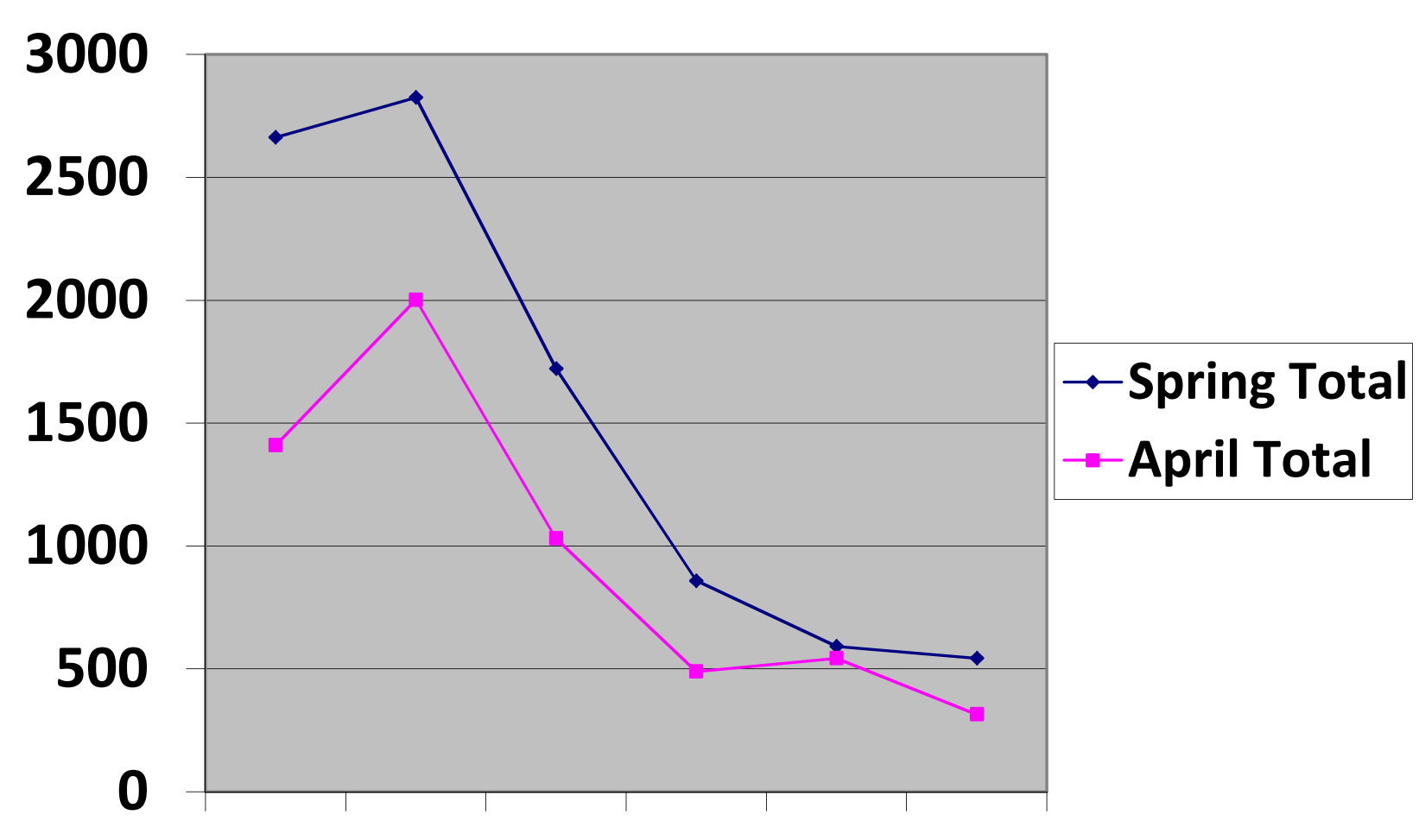

\section{0}

Source: Hawk Migration Association of America, 2010

Figure 5.4 DRRMS Total April and Spring Raptor Count 2004 -2010 


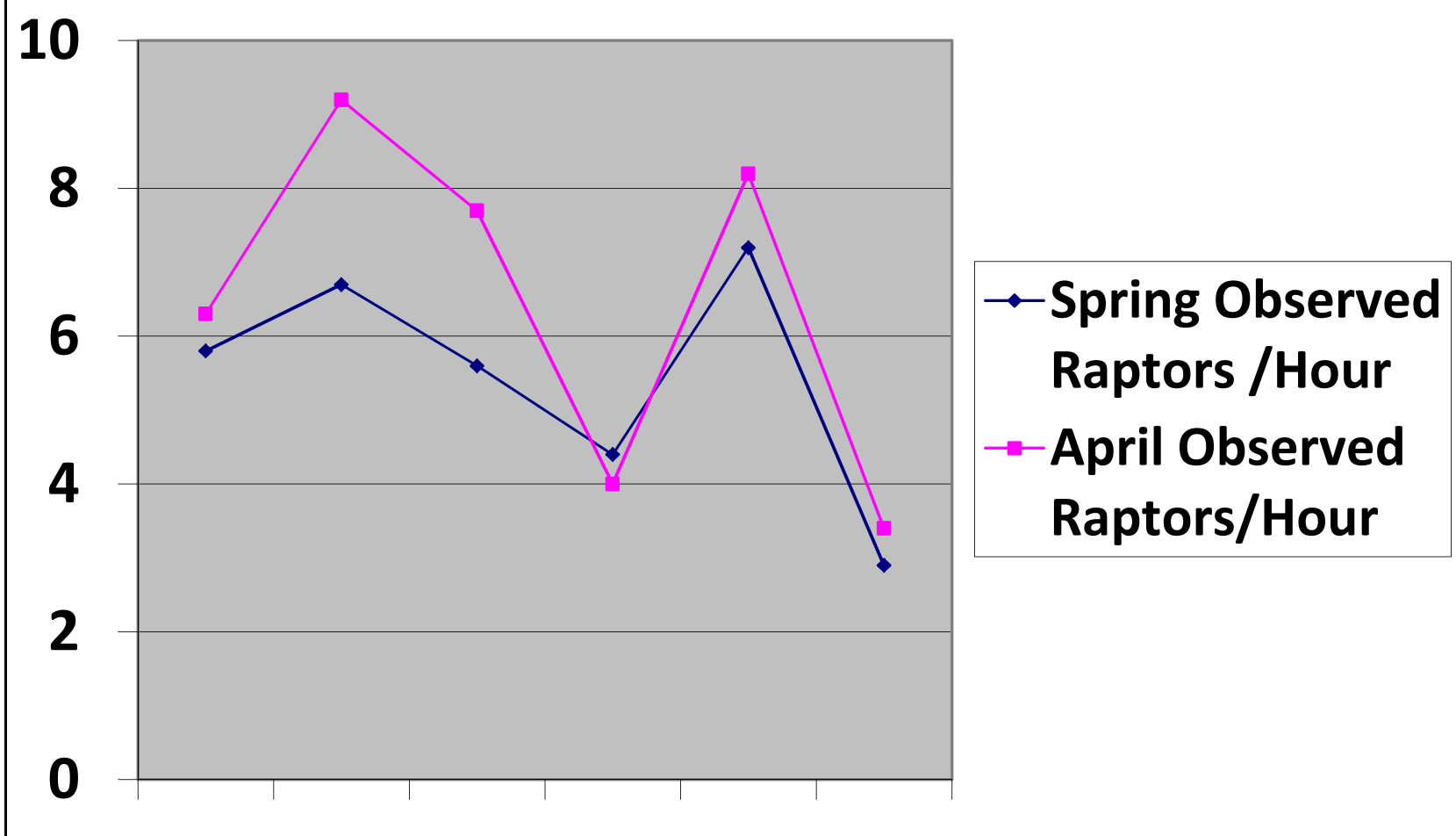

200420052006200820092010

Source: Hawk Migration Association of America, 2010

Figure 5.5 DRRMS Recent Spring and April Migrating Raptors Per Observation Hour 


\subsection{Discussion}

Wind energy development has been shown to pose a risk to birds, and raptors, in particular, from collisions with turbine blades as well as met tower guy wires (Erickson 2001). Raptors, as well as other migratory birds, are protected by the federal Migratory Bird Treaty Act (MBTA, 16 USC 703-71L). Eagles are protected not only by the MBTA, but also by the Bald and Golden Eagle Protection Act (BGEPA [16 USC I.S.C. 668a-668b]). In addition, there is an Executive Order (EO 13186, 2001) which outlines the Responsibilities of Federal Agencies to Protect Migratory Birds. In response to this EO, the US FWS and DOE co-signed a Memorandum of Understanding (MOU) regarding the implementation of this EO (DOE and FWS, 2006).

Because of the collision risks, and the regulatory protection of these species, studies have been undertaken at the NWTC to document the use of the site by birds, including raptors. Although the NWTC is a research facility, and not a wind farm, the presence of aerial structures onsite (turbines and guyed met towers) pose a risk to these species, particularly given the topographical overlap with known northward spring migration routes, and known raptor nesting locations in the area. The data presented in this report were collected to document site use by spring migratory and resident raptors, and their behaviors in relation to onsite aerial structures (i.e., turbines and met towers), and for comparison to historic studies and nearby raptor census counts, to provide insight regarding collision risks.

Diurnal raptors and their ecological relatives, owls and vultures, occur at and near the NWTC as both migrants and residents (it should be noted that a year-long avian survey at the NWTC (2010 - 2011) documented the presence of great-horned owls onsite. The raptor survey in April 2010 only conducted observations during the middle of the day, and did not resume at dusk to survey for owls). The raptor survey conducted at the NWTC in April 2010 provides data regarding raptors that were observed flying over the site, as well as those that flew outside site boundaries. A similar survey was conducted by Monahan (1996), and the results of both surveys are compared in this report. Further, in both 1995 and 2010, raptor counts were conducted at the nearby DRRMS site, located 8 miles to the south of the NWTC, and the results of those surveys are also discussed in this report for comparison purposes.

In the results sections (5.1, Analysis of Current Data, and 5.2, Comparison of Current and Historic Data), data are compared related to the following topics:

- Numbers and species of migratory and resident raptors, observed from the NWTC and at the DRRMS, in 2010, and in 1995

- Numbers and species of migratory and resident raptors observed flying within NWTC airspace in 2010 and in 1995

- Flight heights of migratory and resident raptors observed on the NWTC

- Duration of onsite visits

- Behavior of migratory and resident raptors observed on the NWTC

- Migration routes in 2010 and 1995

A discussion of these comparative results is presented below: 


\subsection{Resident Raptors Observed on the NWTC in 2010 and 1995}

The April 2010 spring raptor migration observations demonstrate that resident species actively utilize the NWTC for hunting, perching, mating, loafing, and sentinel posting. In 2010, the NWTC was within the breeding territories of two red-tailed hawk pairs, and one pair of American kestrels. All three breeding pairs made frequent visits to the NWTC during April 2010, and resident turkey vultures also regularly flew over the site. Two occupied red-tail hawk nests within one-half mile of NWTC were observed during April, but nests of the American kestrels and turkey vultures were not observed. These resident raptors were observed within the NWTC airspace nearly 10 percent of the 95.5 hours of observation during April 2010, averaging 4 visits per day or 0.8 visits per hour. American kestrels were the most frequent onsite visitors. In 1995, Monahan also noted resident red-tailed hawks and American kestrels perching on the NWTC on a regular basis, and also noted perching resident prairie falcons and rough-legged hawks.

In addition to the near-site nesting raptors discussed above, bald eagles, golden eagles, and peregrine falcons were observed and are known to occur in the vicinity of the NWTC during the breeding season. During April 2010 two bald eagles were observed in flight north of the NWTC, and a pair of bald eagles was observed nesting in the Coal Creek drainage channel approximately 2.5 miles northeast of the NWTC. Local ornithologists report five breeding bald eagle pairs existed in Boulder County during 2008-2010 surveys, including the Coal Creek pair (Hallock and Jones 2011). A nesting pair also exists nearby at Standley Lake, in Jefferson County. Local authorities also report from three to five breeding pairs of peregrine falcons currently in the county (Hallock and Jones 2011). In 1995, Monahan observed all three species in the nearby Eldorado Canyon area, and also recorded 15 bald eagle and 13 golden eagle transits of the NWTC during his 17 month survey. EPA (accessed onsite 2013) reports that Home range sizes of bald eagles vary widely depending on the area, season, availability of and distance to food resources, and the breeding status of the individual. For example, breeding eagles in Saskatchewan utilized home ranges greater than 1,730 acres in size, and average home range sizes during breeding season on the Columbia River, OR, was 5,337 acres. A radio-tracked immature bald eagle (non-breeding) from the Southwest U.S. was shown to use summer ranges of more than 13.6 million acres, each, with winter home ranges of more than 5 million acres. As such, the NWTC is within the territories of nearby nesting or winter roosting populations of these raptors, even though none were observed onsite during the 2010 survey.

\subsection{Migratory Raptors Observed on NWTC in 2010 and 1995}

The April 2010 spring raptor migration observations showed that migratory species, as well as residents, also utilize the NWTC for perching, resting, and hunting, although in 2010, only 5 migrants were observed passing within the NWTC airspace. For comparison, the April 1995 raptor survey at NWTC reported 78 raptor overflights of the site (Monahan 1996). The NWTC migratory overflight numbers in 1995 were12-times higher than overflight numbers observed in April 2010 (0.5 raptor/hour [1995] versus 1 raptor/25 hours [2010]). 
A comparison of the numbers and species of raptors observed during spring migration in 1995 and 2010, from observation points at both the NWTC and DRRMS is shown in Table 6.1.

Table 6.1 Comparisons of Spring Migratory Raptor Observations between Years and Sites

\begin{tabular}{|c|c|c|c|c|}
\hline & NWTC 1995 & $\begin{array}{l}\text { DRRMS } \\
1995\end{array}$ & NWTC 2010 & $\begin{array}{l}\text { DRRMS } \\
2010 \\
\end{array}$ \\
\hline Hours of observation & 140 & 140 & 95.5 & 105.5 \\
\hline Number of observations & 290 & 2319 & 127 & 437 \\
\hline Number of species & 14 & 17 & 10 & 17 \\
\hline Raptors/observation hour & 2.07 & 16.6 & 1.32 & 4.14 \\
\hline Most abundant observed & Turkey vulture & Not avail. & Turkey vulture & Not avail. \\
\hline $2^{\text {nd }}$ most abundant observed & Am. kestrel & Not avail. & $\begin{array}{l}\text { Red-tailed } \\
\text { hawk }\end{array}$ & Not avail. \\
\hline $3^{\text {rd }}$ most abundant observed & $\begin{array}{l}\text { Red-tailed } \\
\text { hawk }\end{array}$ & Not avail. & Unid. raptor & Not avail. \\
\hline
\end{tabular}

Onsite data as well as data collected by the Rocky Mountain Bird Observatory since 1995 demonstrate that large numbers of raptors migrate northward in the spring along the Colorado Front Range, although the northward path in relation to the NWTC is variable (i.e., in some years large numbers of raptors have been shown to occur to the west or the east of the NWTC, or within the airspace of the NWTC).

A comparison of on- and offsite data from 1995 and 2010 demonstrate variability in numbers, species, and locations of spring migrants observed (Table 6.1). In both 2010 and 1995, the numbers of species and individuals observed at DRRMS were greater than those observed at the NWTC.

There are several potential explanations in such variability in the numbers of April raptor observations at both the NWTC and DRRMS. For example, in 2010, differences in numbers and species observed between the NWTC and the DRRMS could be attributable to the lack of monitoring on weekend days at the NWTC. In fact, the highest daily April raptor count was Saturday April 10, when DRRMS recorded 98 raptors, or $22 \%$ of the total April tally. In addition, $60 \%$ of migrant American kestrels were observed on weekend days at DRRMS in April 2010 when the NWTC observer was not onsite, while none were observed from the NWTC observation point. In 1995, another explanation put forth by Monahan (1996) is that largebodied raptor species that rely heavily on updrafts were frequently observed passing along the hogback or the initial ridgetop of the mountain top or further to the west. These topographic influences could result in some species preferentially traveling west of the NWTC, and/or the hogback depending on weather patterns in a given year.

At DRRMS, although the same number of species was observed in 1995 compared to 2010, the number of observations decreased from 2319 to 437. The Hawk Migration Association of North America (HMANA 2010) provides data on the internet for all observations recorded at the DRRMS for several years since 2001. From six recent years of recorded data (2004-2006 and 2008-2010), April observations at DRRMS dropped from a high of 2000 observations to less 
than 500 during that timeframe. One possible explanation for variability in counts at DRRMS is that, in the mid-1990s, observers at the DRRMS were paid employees, onsite daily from early morning until dusk. Starting in 2005, observations were made by volunteers, rather than paid employees, and in recent years, there have been fewer volunteers than in earlier years. Volunteers would be less likely to occupy the site for such long hours, every day from midMarch through mid-May (personal communication, J. Birek, 2013).

Another explanation is the annual variability observed in spring migratory raptor routes along the Front Range of Colorado. These migration routes can vary from year to year based on wind and storm patterns. For example, if the wind patterns in a particular year tend to come from the southeast, then raptors normally moving through the eastern plains would be blown westward, and tend to "pile up" along the hogback (personal communication, J. Birek, 2013). These variable wind and storm patterns can result in migration routes that can concentrate over the western foothills, over the hogback, or east of the hogback (including the airspace over the NWTC) out to the eastern plains. In 2010, 45\% of observed migrating raptors passed the site greater than two miles west of the NWTC, while $48 \%$ were observed at intermediate distances $(0$ to 2 miles) west of the NWTC, and seven percent east. In contrast, Monahan's April 1995 observations show the reverse trend: $30 \%$ of raptors observed in a distance tally were located at greater than two miles west, $6 \%$ were observed from 0 to 2 miles west, and $34 \%$ were observed to the east of the NWTC.

In addition, on a regional and national basis, trends showing declines in raptor numbers are emerging. For example, the average annual number of spring migrants passing DRRMS during from 2004 - 2010 was 1570, while Goodrich and Smith (2008) report the annual average at DRRMS from 1990 to be 3908 raptors. This is similar to four other intermountain west migration monitoring sites; the average annual spring migration count for this set of locations is 3557 raptors, very similar to the DRRMS annual average. However, in the last three years (2008 to 2010) total numbers have not reached 1000. In addition, according to analyses conducted by the Raptor Population Index (2010) Project, data show that across 28 North American raptor monitoring sites from 1995 to 2005: American kestrel numbers are declining at 82\% of the sites (although this is more prevalent in the eastern US, due to habitat destruction and reduced open hunting spaces [personal communication, J. Birek, 2013]); turkey vulture is increasing at 57\%, red-tailed hawk is decreasing at $65 \%$, golden eagle is decreasing at $50 \%$, Coopers' hawk is decreasing at $54 \%$, and bald eagle is decreasing at $25 \%$ of the sites.

Given that migration is still not completely understood by scientists, it is recognized that there are likely other explanations for variability in numbers and species observed at the NWTC and DRRMS, such as variable weather patterns, habitat changes, and other factors not yet understood. Scientists are still studying migration cues, strategies, mode of flight, weather pattern influences, and what guides migration. While this makes generalizations difficult, future variability in the numbers of migrants passing through NWTC, whether greater or less than those observed in 2010 , should be expected. 


\subsection{Flight Heights of Raptors in NWTC Airspace}

During April 2010 observations, a total of five migrant raptors entered the NWTC airspace and were observed at heights ranging from 0 to $20 \mathrm{~m}$ ( 0 to $65 \mathrm{ft}$ ) while hunting, and 60 to $250 \mathrm{~m}$ (197 to $820 \mathrm{ft}$ ) while flying through the area. The Cooper's hawk, observed hunting, spent $10 \mathrm{~min}$. onsite, while the other species passing through the site spent 2 min. or less. Resident raptors (American kestrel, red-tailed hawk, turkey vulture, unidentified Falco, unidentified Buteo, and unidentified raptor) were observed much more frequently onsite ( 82 raptor observations totaling 8.8 hours of time onsite during weekday observations). Flight heights for the resident raptors ranged from 0 to $320 \mathrm{~m}(1050 \mathrm{ft})$.

For comparison purposes, the height of the shortest onsite turbines (measured from ground to bottom of nacelle) are $9 \mathrm{~m}(30 \mathrm{ft}$.) with a $3.7 \mathrm{~m}(12 \mathrm{ft}$.) rotor diameter. The rotor on this size turbine reaches approximately half the diameter (i.e., $1.85 \mathrm{~m}$, or $6 \mathrm{ft}$. above and below the nacelle, or $7.3 \mathrm{~m}$ to $10.85 \mathrm{~m}$ [ 24 to $36 \mathrm{ft}$.] above the ground surface [ags]). The height of the tallest onsite turbine is $90 \mathrm{~m}$ ( $295 \mathrm{ft}$.) with a $100 \mathrm{~m}$ ( $328 \mathrm{ft}$.) rotor diameter. The rotor on this size turbine reaches approximately $50 \mathrm{~m}(164 \mathrm{ft}$.) above and below the nacelle, or $40 \mathrm{~m}$ to $140 \mathrm{~m}(131$ to 459 ft.) ags. Met towers range from 30' high, with one level of guy wire connections and 3 anchors, to $443^{\prime}$, with 6 levels of guy wire connections, and 6 anchor points.

Table 6.2 Comparisons of Observed Raptor flight Heights in NWTC Airspace to Heights of Onsite Aerial Structures

\begin{tabular}{|l|l|l|l|l|l|l|l|l|}
\hline & $\begin{array}{l}\text { Migrant } \\
\text { flight } \\
\text { heights } \\
\text { when } \\
\text { hunting } \\
\text { (ft) }\end{array}$ & $\begin{array}{l}\text { Migrant } \\
\text { flight } \\
\text { heights } \\
\text { when } \\
\text { flying } \\
\text { through } \\
\text { the area }\end{array}$ & $\begin{array}{l}\text { Resident } \\
\text { flight } \\
\text { heights } \\
\text { (ft) }\end{array}$ & $\begin{array}{l}\text { Shortest } \\
\text { turbine } \\
\text { heights } \\
\text { (ft) }\end{array}$ & $\begin{array}{l}\text { Range } \\
\text { of rotor } \\
\text { diameter } \\
\text { above } \\
\text { the } \\
\text { ground }\end{array}$ & $\begin{array}{l}\text { Tallest } \\
\text { turbine } \\
\text { heights } \\
\text { (ft) }\end{array}$ & $\begin{array}{l}\text { Shortest } \\
\text { met } \\
\text { tower } \\
\text { (ft) }\end{array}$ & $\begin{array}{l}\text { Highest } \\
\text { met } \\
\text { tower (ft) }\end{array}$ \\
\hline $\begin{array}{l}\text { shortest } \\
\text { ht. }\end{array}$ & 0 & 197 & 0 & 30 & & & 30 & \\
\hline $\begin{array}{l}\text { Highest } \\
\text { ht. }\end{array}$ & 65 & 820 & 1050 & & & 295 & & 443 \\
\hline $\begin{array}{l}\text { shortest } \\
\text { blade ht. } \\
\text { ags }\end{array}$ & & & & & 24 & 131 & & \\
\hline $\begin{array}{l}\text { Highest } \\
\text { blade ht. } \\
\text { ags }\end{array}$ & & & & & 36 & 459 & & \\
\hline $\begin{array}{l}\text { Levels } \\
\text { of } \\
\text { guywires }\end{array}$ & & & & & & & & \\
\hline $\begin{array}{l}\text { No. of } \\
\text { anchors }\end{array}$ & & & & & & & 3 & 6 \\
\hline
\end{tabular}


Comparison of observed flight heights of both migratory and resident raptors with heights of onsite aerial structures indicates that raptors fly at heights consistent with risks of collision with turbine blades or met tower guy wires.

\subsection{Duration of Onsite Raptor Visits}

In the "Analysis of Current Data" section of this report (Section 5.1), Figure 5.2 shows that resident raptors made shorter duration visits much more frequently than long ones, with 58 raptor visits of $5 \mathrm{~min}$. or less, 15 visits from 5 to $17 \mathrm{~min}$. duration, 6 visits from 20 to $33 \mathrm{~min}$. duration, and two raptor visits of 48 minutes. Short visits of resident raptors were likely to be mostly flights through or transiting the site, as well as mating and hunting activities, while longer duration visits during this survey were primarily perching events which did not involve much more flight time than the short duration transits. Raptors were observed perching on tall vegetation, poles or posts, trees, met towers, and guy wires. Migrant raptor visits to the site in 2010 ranged in duration from 1 to $2 \mathrm{~min}$. for those raptors transiting the site, to $10 \mathrm{~min}$. for one raptor involved in hunting activities. The small number of migrants observed onsite in $2010 \mathrm{did}$ not engage in hunting (other than one Cooper's hawk), courtship, or territory defense behaviors because 1) their movement appeared to be concentrated several miles to the west over mountainous terrain, resulting in very few visits to, or overflights of, the site (based on one season of observation), and 2) the larger, soaring species do not feed regularly during migration, minimizing the need to visit the site. Although larger raptors such as eagles, vultures, and ospreys feed infrequently during migrations, small-winged raptors such as the falcons and accipiters, feed more regularly. Larger raptors do not rely on powered flight except to reach gliding altitude and thus require fewer calories to successfully migrate. Smaller winged, powered flight species expend much more energy per unit mass to such an extent that they migrate synchronously with song bird prey populations (Newton 2008).

Superficially, it may seem like less time spent onsite would reduce the risk of collision with aerial structures or guy wires. However, raptor behavior must be considered along with time spent onsite to understand the overall risk to onsite raptors from structures and guy wires. For example, when a raptor sees a prey object, the tendency is to lock eyes on the object while flying towards it, and not pay attention to other landscape features. As such, a reduced amount of time onsite would not necessarily correlate with a reduced risk of collision. In addition, stochastic, or random, events such as guywire collisions are proportional to exposure, such that the probability of collision would likely increase in proportion to increases in the number of guywires.

During this survey, resident raptors engaged in semi-constant use of the NWTC landscape, particularly tall towers and guywires. Although no collisions or dead birds were observed from collisions with onsite structures in April 2010, from 2008 to 2010 two nocturnal raptors (great horned owl [Otis asio]) and one diurnal raptor (red-tailed hawk [Buteo jamaicensis]) fatalities occurred on the western portion of the NWTC. In addition, an injured Swainson's hawk (Buteo swainsoni) was found beneath the utility-scale turbine at site 4.2 , on the eastern portion of the site, and was transported to a raptor rehabilitation facility located in Broomfield, Colorado (Beatty, personal communication). 


\subsection{CONCLUSIONS}

Both resident and migratory raptors were observed during the 1995 and 2010 surveys to fly through the NWTC airspace or to use onsite habitat for hunting, perching, mating, or sentinel posting. In addition, nearby nesting sites and roosting were documented during both surveys for bald eagles, golden eagles, and peregrine falcons, in both Jefferson and Boulder counties. While no eagles or peregrine falcons were observed using the site during the weekday only surveys in 2010, they were observed onsite in 1995 (Monahan 1996). Nearby nesting locations of eagles and peregrine falcons, coupled with large home ranges and hunting territories, and onsite observations outside of survey periods, indicate site use does occur by these large raptors.

Comparison of onsite data from 1995 and 2010 show that onsite use by raptors is variable on a year-to-year basis. Numbers of raptors observed at the nearby DRRMS have also been shown to be variable. Factors affecting variability include presence/absence of onsite observers throughout the survey periods, fewer hours of onsite observation in 2010 compared to 1995 (i.e., 95 hours vs 140 hours, respectively), wind and storm patterns, shifts in routes of migration along the Front Range, and other less understood factors. Low numbers of migratory raptors (i.e., 5) used the site during April 2010, while higher numbers of resident raptors (i.e., 81 separate observations) used the site in 1995.

Both migratory and resident raptors using the NWTC were observed in 2010 to fly through the site at heights of onsite aerial structures (turbine rotor swept areas, and guyed met towers). In 2010, while only 5 migratory raptors were observed onsite, resident raptors were observed using the site nearly 10 percent of the observation time. During this time, shorter duration visits (transiting the site, on onsite hunting/mating activities) occurred much more frequently than longer duration site visits (mostly associated with perching events). While shorter duration visits may seem to indicate reduced risk of collision, raptor behavior during hunting activities is more likely to increase the risk of collision.

Although no collisions or dead birds were observed from collisions with onsite structures in April 2010, from 2008 to 2010 two nocturnal raptors (great horned owl) and one diurnal raptor (red-tailed hawk) fatalities occurred on the western portion of the NWTC, and an injured Swainson's hawk was found beneath one of the utility-scale turbines on the eastern edge of the site (Beatty, personal communication). While these numbers may appear low, it should be noted that both the Migratory Bird Treaty Act and the Bald and Golden Eagle Protection Act prohibit "take" of individuals, and do not address population level effects.

The results of the 2010 survey represent the April mid-day, weekday portion of Spring raptor observations for one year, and because of annual variations, does not represent the norm or average springtime raptor presence at the NWTC. That is, numbers of migratory and resident raptors using or flying over the NWTC could be greater or less than 2010 in future years.

\subsection{Recommendations}

As a federal agency, DOE (and therefore, NREL) has an obligation to comply with other federal laws (MBTA, BGEPA), Executive Orders (13186), and Agency Directives, and to work collaboratively with other federal agencies (e.g., USFWS). In addition, in response to these (and other) regulatory requirements, NREL has developed policies and procedures that address 
environmental stewardship, protection of natural resources, and compliance with environmental laws. These Policies and Procedures include the following:

- Policy 6-2, Environmental Protection, which commits to onsite continual improvement in environmental and sustainability performance regarding environmental stewardship practices,

- Policy 2-7, Sustainable NREL, which stresses managing the impact on the environment caused by the placement and general design of NREL structures, and maintaining, protecting, and restoring natural environments to sustain natural and native ecological systems,

- Procedure 6-2.2, National Environmental Policy Act Implementation, which requires compliance with other federal laws, Executive Orders, etc., and

- Procedure 6-2.21, Natural Resource Conservation, which commits to avoiding, minimizing, and mitigating impacts to natural resources, and to comply with NEPA.

Further, two Memoranda of Understanding have been signed by DOE that address the protection and conservation of natural resources. These include the following:

- MOU between DOE and FWS Regarding Implementation of EO 13186, "Responsibilities of Federal Agencies to Protect Migratory Birds" (OMS 2001), which includes the following DOE responsibilities:

- Implementing management practices that avoid or minimize adverse effects on migratory bird populations, and their nesting, foraging, migration, staging, or wintering habitats, including the use of effective techniques to minimize the risk of collisions with structures, and

- Consider FWS recommendations and suggested practices regarding energy development to avoid or minimize direct and indirect effects on migratory birds and their habitats.

- MOU between the Trustee Council for Natural Resources at Rocky Flats and DOE's Office of Energy Efficiency and Renewable Energy (2009), which commits EERE to the following:

- Manage and operate the NWTC consistent with the Natural Resource Conservation Plan (NREL Procedure 6-2.21), and

- Take appropriate action to mitigate adverse impacts of NREL development activities on natural resources at the NWTC.

These obligations emphasize the importance of implementing procedures at the NWTC to avoid and minimize additional mortalities to resident and migratory raptors onsite. Based on the results of onsite raptor surveys and the above obligations, recommendations include the following:

- Implement and follow the practices outlined in the FWS Land-Based Wind Energy Guidelines (USFWS 2012), including the use of bird diverters or other visibility markers on guy wires, 
- Conduct onsite monitoring after incorporating the Best Management Practices (BMPs) in the FWS Land-Based Wind Energy Guidelines, to evaluate effectiveness

- Develop an Avian Protection Plan for the NWTC

- Mow in the vicinity of aerial structures, and remove large rock piles that attract small mammal prey species

- Install alternate raptor sentinel stations offsite in a food rich area to lure raptors away from the NWTC.

The development of the FWS Land-Based Wind Energy Guidelines was a collaborative effort among federal agencies (including DOE), wind industry representatives, and conservation organizations. These guidelines include BMPs recommending the use of monopole, rather than guyed towers (if towers must be guyed, then bird diverters or other visible marking devices should be used), using tubular towers to reduce ability of birds to perch and reduce risk of collision, placing power lines underground, using the minimum number of met towers, using red, or red and white flashing lights, not steady burning bulbs, extinguishing all internal turbine nacelle and tower lighting when unoccupied, and removing turbines and guyed met towers that are not in use.

The effectiveness of bird diverters on guywires is currently being studied at numerous sites, and current results indicate that the effectiveness is not only site-specific, but also species-specific. As such, results indicating that they are or are not effective cannot be applied across-the-board. It is recommended that once installed on guy wires at the NWTC that a formalized monitoring program be implemented to ascertain the site-specific effectiveness at the NWTC, with the species known to use the site.

If alternate raptor sentinel stations (structures that are higher than nearby nest sites, which allow an observation position to assure nest safety) could be located offsite in a food rich area, this could serve to lure raptors away from the NWTC airspace, which would help mitigate onsite mortalities

While the relatively low number of structures in a small area impinges on many fewer breeding or wintering raptor territories in comparison to a site like the 68 square mile Cedar Creek II Wind farm in Weld County, Colorado, implementing the FWS guidelines would help mitigate mortalities for species that currently appear to be declining in number, and would demonstrate compliance with regulatory requirements and NREL policies and procedures. 


\subsection{References}

Baldeagleinfo.com. 2012. American Bald Eagle Information, General Facts. Downloaded at: http://www.baldeagleinfo.com/eagle/eagle-facts.html.

Beatty, Brenda. Personal Communication. Written comments to John DuWaldt from Brenda Beatty, National Renewable Energy Laboratory. ECO+logic LLC, Evergreen, CO.

Berry, M.E.; Bock, C.E. (1998). "Effects of Habitat and Landscape Characteristics on Avian Breeding Distributions in Colorado Foothills Shrub." Southwestern Naturalist (43): pp. 453-461.

Birek, Jeff. Personal Communication. Telephone conversation between Brenda Beatty and Jeff Birek, Rocky Mountain Bird Observatory. NREL, Golden, CO.

Chesser, R. Terry, R. C. Banks, F. K. Barker, C. Cicero, J. L. Dunn, A. W. Kratter, I. J. Lovette, P. C. Rasmussen, J.V. Remsen, Jr., J.D. Rising, D.F. Stotz, and K. Winker, 2009. Fiftieth Supplement to the American Ornithologists' Union Check-List of North American Birds. The Auk 126(3: 705-714).

Department of Energy (DOE) and U.S. Fish and Wildlife Service (FWS), 2006). Memorandum of Understanding Between the United States Department of Energy And the United States Fish and Wildlife Service Regarding Implementation of Executive Order 13186, "Responsibilities of Federal Agencies to Protect Migratory Birds". August 3.

EPA. EcoRisk Profile Bald Eagle.

http://www.epa.gov/region1/ge/thesite/restofriver/reports/final_era/B\%20\%20Focus\%20Species\%20Profiles/EcoRiskProfile bald eagle.pdf. Accessed May 3, 2013.

Erickson, E.P., G.D. Johnson, M.D. Strickland, K.J. Sernka, and R.E. Good. 2001 Avian Collisions with Wind Turbines: A Summary of Existing Studies and Comparisons to Other Sources of Avian Collision Mortality in the United States. Prepared by WEST, Inc., Cheyenne, WY. National Wind Coordinating Committee, Washington, D.C.

Erickson, W., J.A. Shaffer, D. Strickland, and D.H. Johnson, 2007. Protocol for Investigation Displacement Effects of Wind Facilities on Grassland Birds. Internet Center for Wildlife Damage Management, USGS Northern Prairie Wildlife Research Center, University of Nebraska. Lincoln, NE.

Executive Order (EO) 13186, 2001. Responsibilities of Federal Agencies to Protect Migratory Birds. January 10. http://ceq.hss.doe.gov/nepa/regs/eos/eo13186.html. Accessed April 29, 2013.

Federal Register, 2010. 50 CFR Parts 10 and 21, General Provisions; Migratory Birds Revised List and Permits; Final Rules. Department of Interior, USFWS. U.S. Government Printing Office, Washington, D.C. Vol. 75, No. 39 pp. 9282. Monday, March 1. 
Goodrich, L.J. and J.P. Smith. 2008. Raptor Migration in North America. Pp. 37-150 in K.L. Bildstein, J.P. Smith, E. Ruelas I., and R.R. Veit (eds). State of North America.s Birds of Prey. Nuttall Ornithological Club and American Ornithologists. Union Series in Ornithology No. 3. Cambridge, Massachusetts, and Washington, D.C. [TP-09]

Hallock, Dave and Stephen Jones, 2011. Boulder County Avian Species of Special Concern. Boulder County Nature Association. Boulder, Colorado.

Hawk Migration Association of North America (HMANA), 2010. Dinosaur Ridge Count Site Web Page:

http://hawkcount.org/month_summary.php?rsite=123\&ryear=2010\&month $=04 \& s e c=k e y$. Accessed May 10, 2010.

Manville, A. M., 2005. Bird Strikes and Electrocutions at Power Lines, Communication Towers, and Wind Turbines: State of the Art and State of the Science - Nexts Steps Toward Mitigation. USDA Forest Service General Technical Report. PSW-GTR-191.

Monahan, M.W., 1996. Raptor Presence in and Around the National Wind Technology Center: An Assessment of Risks and Management Alternatives. Final Report, NREL, Golden, CO.

Newton, Ian, 2008. The Migratory Ecology of Birds. Academic Press, New York.

Remsen, J.V., Jr., C.D. Cadena, A. Jaramillo, M.Nores, J.F. Pacheco, M.B. Robbins, T.S. Schulenberg, F. G. Stiles, D. F. Stotz and K.J. Zimmer, 2007. A Classification of the Bird Species of South America. American Ornithologists' Union. http://www.museum.Isu.edu/ Remsen/SACCBaseline.html

Office of Management Systems (OMS), 2001. Executive Order 13186. Responsibilites of Federal Agencies to Protect Migratory Birds. The White House. January 10.

Raptor Population Index, 2010. Raptor Population Index: Trend Graphs. http://www.rpiproject.org/rpigrapht.php

Schmidt, E., A.J. Piaggio, C.E. Bock, and D.M. Armstrong, 2003. National Wind Technology Center Site Environmental Assessment: Bird and Bat Use and Fatalities - Final Report. NREL, Golden, CO. NREL/SR-500-32981.

Trustee Council for Natural Resources at Rocky Flats and the Office of Energy Efficiency and Renewable Energy, U.S. Department of Energy. 2009. Memorandum of Understanding. June 30 .

U.S. Department of Energy, 2002. Final Site-Wide Environmental Assessment of National Renewable Energy Laboratory's National Wind Technology Center. U.S. DOE, Golden Field Office, NREL, Golden, CO. 
U.S. Department of Energy, 2010. Study Plan: Monitoring Avian Use and Mortality. NREL, National Wind Technology Center. Golden, CO. Submitted by: Western EcoSystems Technology, Inc., Cheyenne, WY. March 27.

U.S. Fish and Wildlife Service. 2012. U.S. Fish and Wildlife Service Land-Based Wind Energy Guidelines. OMB Control No. 1018-0148. March 23. 